\title{
Articles
}

\section{Constitutional Economics}

\author{
Luke Norris*
}

The conventional narrative that courts and legal scholars tell about the repudiation of Lochnerism in the late 1930s is incomplete. The standard view is that the Lochner line of cases 1 - those overturning state wage and hour laws under substantive due process doctrine ${ }^{2}$ - collapsed as their premises about economic liberty were undermined. ${ }^{3}$ The doctrine then remained dormant until it was revived in Griswold v. Connecticut. ${ }^{4}$ The account continues that the aim of substantive due process jurisprudence in the post-Griswold era, as the Supreme Court turned to vindicating personal and intimate rights under the doctrine, has been to distinguish the modern doctrine from Lochnerism. ${ }^{5}$ Yet this view ignores how the architects of the New Deal era repudiated Lochnerism and how their affirmative constitutional argument connects to modern substantive due process doctrine. $^{6}$

The conventional account is not incorrect, but it is incomplete. The

* Associate-in-Law, Columbia Law School. For generous feedback and input, I thank Bruce Ackerman, Guido Calabresi, Adam D. Chandler, R. Michael Fischl, Owen Fiss, Heather Gerken, Kent Greenawalt, Jamal Greene, Claudia Haupt, Jeremy Kessler, Justin Lo, Henry Monaghan, Allison Tait, and participants in the Associates \& Fellows workshop at Columbia Law School. I also thank Mark Pinkert and all of the editors for their excellent work and helpful contributions.

1. Lochner v. New York, 198 U.S. 45 (1905). Jamal Greene shows that for much of the 20th century, Lochner "itself was no more significant within the judicial imagination than were other cases standing for similarly discredited notions of substantive review of social and economic legislation." Jamal Greene, The Anticanon, 125 HARV. L. REV. 379, 447 (2011). In the late 1960s, however, Lochner "became a useful foil to Griswold v. Connecticut and its substantive due process progeny." Id. With this in mind, I refer generally to "Lochnerism."

2. Under the doctrine, courts read the Fifth and Fourteenth Amendments' Due Process Clauses to offer a "substantive guarantee of liberty." U.S. CONST. amend. V ("No person shall . . be deprived of life, liberty, or property, without due process of law ...."); U.S. CONST. amend. XIV, $\S 1$ ("No State shall ... deprive any person of life, liberty, or property, without due process of law . ..."); Kenji Yoshino, The New Equal Protection, 124 HARV. L. REV. 747, 779 (2011).

3. See infra Part 1.A for an overview of the conventional view of the repudiation of Lochnerism.

4. Griswold v. Connecticut, 381 U.S. 479 (1965).

5. See infra Part 1.B.

6. My references to Lochnerism are confined to Lochnerism within substantive due process doctrine and its demise there. There is a separate literature on how the logic of Lochnerism has been transported into First Amendment doctrine. See, e.g., Cass Sunstein, Lochner's Legacy, 87 CoLum. L. REV. 873, 883-85 (1987); Howard Wasserman, Bartnicki As Lochner: Some Thoughts on First Amendment Lochnerism, 33 N KY. L. REV. 421 (2006). 
conventional account is correct that Lochnerism was undermined on its own terms. The Court, in West Coast Hotel Co. v. Parrish, in upholding a Washington State wage and hour law, came to view the relationship between employers and employees as one evincing unequal bargaining power more so than willful freedom of contract. ${ }^{7}$ It therefore concluded that the law did not interfere with the liberty protected by substantive due process doctrine, undermining the Lochnerian view of liberty of contract premised on employer-employee parity. The conventional narrative misses, however, how the nation came to accept an alternative and affirmative view of economic liberty focused on worker association. The architects of the New Deal order were not satisfied merely to challenge the contractarian model underlying Lochnerism. They argued that just as the political freedom at the center of our constitutional order was defined by associative participation in self-government, ${ }^{8}$ so too was economic freedom in an industrial order defined by associative participation in worker selfgovernment in labor unions. The history of the repudiation of Lochnerism therefore becomes a story about the adoption of a view of economic liberty based on mutual association.

My first endeavor in this Article is to explore more fully the repudiation of Lochnerism. I focus in Part I on the conventional narrative about Lochnerism and its decline, and characterize the forms of constitutional reasoning and ethical argument related to it. I then flesh out at a high level the ethical and purposive constitutional argument underlying the challenge to Lochnerism. ${ }^{9}$ I turn in Part II to the history of the development of the counter-narrative supporting this argument, exploring how it was elaborated by the labor movement - and in particular, the American Federation of Labor ("AFL") and its leaders - and how leaders within the three branches of the federal government adopted this competing argument about worker freedom. ${ }^{10}$ I trace the narrative about economic freedom from the labor

7. 300 U.S. 379 (1937); see also infra Part II.B.

8. See infra Part II.B.

9. Other scholars refer to a series of related arguments, spanning from Jacksonian democracy through the New Deal, about republican self-government as structural arguments. Joseph Fishkin \& William Forbath, The Anti-Oligarchy Constitution, 94 BosTON U. L. REV. 671, 686-87 (2014). This characterization may be correct, since they are addressing the issue of oligarchy in their broad study, which seems to be more directly related to the relationship between government and citizens that is included within structural argument. See CHARLES BLACK, STRUCTURE AND RELATIONSHIP IN CONSTITUTIONAL LAW 17 (2000). But since structural arguments, as I see them, are generally about the interaction between governmental structures themselves and those structures and citizens, and since ethical and purposive arguments are about the meaning and purpose of fundamental commitmentsincluding the scope of republicanism's requirement that citizens possess the independence and agency that qualifies them for self-governing - I prefer the use of ethical and purposive as labels for the types of constitutional arguments that I am presenting in this Article.

10. Labor law scholars have written rich histories of the movement's arguments about inequality and freedom, and the movement's' constitutional arguments sounding in the First, Fourteenth, and even Thirteenth Amendments. See, e.g., infra note 67. Some of those histories reference the freedom of contract jurisprudence in the courts and Lochnerism. See, e.g., Mark Barenberg, The Political Economy 
movement through Congress as it passed the National Labor Relations Act of 1935 ("NLRA"), "1 which provided workers with collective bargaining rights; through the Executive as FDR campaigned for reelection in 1936; and into the Supreme Court as it upheld the NLRA in NLRB v. Jones \& Laughlin Steel Company. ${ }^{12}$

As the Article shows, the two competing narratives are animated by differences in approach to constitutional political economy. ${ }^{13}$ On one side, the forces behind Lochnerism focused on having courts strike down wage and hour laws in the battle to define economic liberty. Such laws, they argued, deprived workers and employers of liberty of contract and violated substantive due process doctrine. On the other side, the labor movement and congressional and executive leaders were focused on protecting worker association through legislation and viewed worker freedom of association as the paradigm of economic liberty protected by the Constitution. ${ }^{14}$

To redefine economic liberty, these New Deal architects were mainly focused on a particular kind of worker legislation. Significant parts of the labor movement had a complicated relationship with wage and hour laws like those overturned under Lochnerism, for fear that if enacted they would set wage floors and ceilings, ${ }^{15}$ and, although the most powerful forces within the labor movement ultimately supported wage and hour laws, the labor movement was most keenly focused on protecting worker association. By the time of the New Deal, the movement and leaders in Congress and the Executive were determined to prevail in the struggle to define economic liberty by building out the national government to enact collective bargaining guarantees that provided for worker freedom of association. They pursued the route of building out the state through legislation that sought to achieve constitutional purposes-what one scholar has called

of the Wagner Act: Power, Symbol, and Workplace Cooperation, 106 HARV. L. REV, 1379, 1445-48 (1993); William E. Forbath, The New Deal Constitution in Exile, 51 DUKE L. J. 165, 196-98 (2001). This Article both builds on their work and ties labor's argument more strongly to the decline of Lochnerism and the rise of post-Griswold substantive due process.

11. See Pub. L. No. 64-198, 49 Stat. 449 (1936) (codified at 29 U.S.C. $§ 151-169$ ).

12. 301 U.S. 1 (1937). Many studies of the constitutional significance of the New Deal take this approach of looking beyond the courts alone. See, e.g., BRUCE ACKERMAN, WE THE PEOPLE: FOUNDATIONS (1993) (assessing Congress and the Executive, in addition to the Supreme Court, in their leadership roles in transformation); CASS SUNSTEIN, THE SECOND BILL OF RIGHTS: FDR'S UNFINISHED REVOLUTION AND WHY WE NEED IT MORE THAN EVER (2004) (assessing the role of Congress and the Executive in creating constitutive commitments). It is also an approach taken by many scholars. See, e.g., SANFORD LeVINSON, CONSTITUtional FATTH 27-30 (1998); Robert C. Post \& Reva B. Siegel, Legislative Constitutionalism and Section Five Power: Policentric Interpretation of the Family and Medical Leave Act, 112 YALE L. J. 1943, 2023 (2003).

13. See Fishkin \& Forbath, supra note 9, at 671 ("arguments about constitutional political economy begin from the premises that economics and politics are inextricable, and that our constitutional order rests on a political-economic order").

14. U.S. CONST, amend. XIV, $\S 1$ ("No State shall ... deprive any person of life, liberty, or property, without due process of law ....").

15. See, e.g., Frances Perkins, THe RoOsevelt I KNew 257-58 (1946); William E. Forbath, LAW AND THE SHAPING OF THE AMERICAN LABOR MOVEMENT 17, 55 (1991). 
"constitutional construction"- and ultimately prevailed in doing so. ${ }^{16}$ The fall of Lochnerism's constitutional vision of economic liberty therefore coincided with the rise of labor's.

After unpacking labor's constitutional argument and presenting a fuller account of the repudiation of Lochnerism, I turn to analyzing its significance for modern doctrine. As I explore in Part III, the story of the fall of Lochnerism would be importantly linked to aspects of the story of the rise of post-Griswold substantive due process. Both are in part constitutional transformations where forms of association that are conceived of as being "non-political" come to be viewed as exercises of freedom worthy of constitutional protection. ${ }^{17}$ While worker association was the paradigm during the New Deal in the economic sphere, intimate association became the paradigm of associational freedom in the postGriswold era in the personal sphere. ${ }^{18}$ Thus, while the modern Supreme Court may be running from the ghost of Lochnerism as it fashions its substantive due process doctrine, its intimate association reasoning picks up on forms of constitutional argument related to Lochnerism's demise.

To be sure, the post-Griswold doctrine provides a somewhat weaker account of associational freedom than the New Deal variant. This is in part because the post-Griswold substantive due process cases analyzed in this Article have at least two strands, which are sometimes both operative in the same opinion. One strand is a privacy strand, focused on individuals and negative liberty - that is, freedom from government interference. Cases like Roe v. Wade ${ }^{19}$ and Planned Parenthood of Southeast Pennsylvania $v$. Casey, ${ }^{20}$ in part because they involve bodily control and integrity, sound strongly in the right to be let alone, or in negative liberty. Cases like Griswold and Obergefell, I argue, are more directly related to the New Deal account of freedom because of their focus on how freedom is exercised in "non-political" association. The liberty interest in Griswold and Obergefell, that is, involves more than the negative conception of state non-interference.

Beyond intimate association, however, I argue that the logic animating

16. See, e.g., JACK M. BALKIN, LIVING ORIGINALISM 3-6 (2011) (describing how constitutional constructions, including New Deal statutes, build out the state in order to serve constitutional purposes).

17. Throughout the Article, I employ the distinction between "political" and "non-political" spheres to refer to categorizations often employed by courts and scholars. See, e.g., Griswold, 381 U.S. at 483 (noting that the Court has "protected forms of 'association' that are not political in the customary sense but pertain to the social, legal, and economic benefit of the members"); Aviam Soifer, Freedom of Association: Indian Tribes, Workers, and Communal Ghosts, 48 MARYLAND L. REV. 350, 363 (1989) (distinguishing between associations based on religious, political, and economic matters and subjects). I do not take a position on the validity of the distinction but instead attempt to show how, maintaining it, the New Deal constitutional transformation and strands of the modern substantive due process transformation align.

18. See, e.g., Obergefell v. Hodges 576 U.S. _ (2015), slip. op. at 14 (recognizing a right to intimate association).

19. 410 U.S. 113 (1973).

20. 505 U.S. 833 (1992). 
the New Deal repudiation of Lochnerism played a limited but still important role in other areas of post-Griswold substantive due process jurisprudence. As I explore in Part IV.E, the lasting import of the New Deal transformation was to undo a tradition of thinking of liberty in "private" spheres solely in negative liberty terms. By disrupting the notion that spheres beyond the "political" sphere would naturally become ordered to allow for individual liberty, and by focusing instead on the economic sphere as a complex domain of governance and organization, the era paved the way for Americans to take account of the social and relational conditions of freedom in other "non-political" spheres. And thus, even in the cases focused most on privacy, which sound strongly in government non-interference, the Court pivoted between speaking of negative liberty and positive liberty. These cases therefore exhibit what I refer to as a mixed tradition. Thus, even the post-Griswold cases that do not link freedom and association are in another way connected to the New Deal transformation.

Indeed, the way that scholars reason about the post-Griswold jurisprudence links it to the logic animating the New Deal transformation that this Article presents. Some scholars have concluded, for example, that in the post-Griswold cases, the Court defined intimate liberty in terms of a "personal version of self-government." ${ }^{21}$ Building on this, others have noted that the Court thus turned to protecting positive liberty ${ }^{22}$ and liberty in domains of collective decision-making beyond the political sphere. ${ }^{23}$ As this Article explores, these are the moves that New Dealers made with economic liberty: analogizing labor association to political self-government and emphasizing the positive and exercise-based aspects of freedom in social contexts beyond the "political" sphere.

This Article therefore disrupts the understanding that a waning gap separates the early-mid twentieth century and the post-Griswold era and connects the two constitutional transformations. The way that the Supreme Court misinterprets the history of the repudiation, however, obscures from its view lessons from the early-mid twentieth century. Thus, while the Court recognizes a right to intimate association, it does not understand how it, in fact, continues a New Deal tradition and misses the opportunity to draw from the New Deal reservoir of reasoning.

This Article proceeds in three Parts. In Part I, I explore the standard view of the rise and fall of Lochnerism and outline the competing argument. In Part II, I explore how the New Deal architects made this competing argument about economic liberty and worker association and how this

21. Laurence H. Tribe, Lawrence v. Texas: The "Fundamental Right" that Dare Not Speak Its Name, 117 HARV. L. REV. 1893, 1939 (2004).

22. See Pamela S. Karlan, Loving Lawrence, 102 MICH. L. REV. 1447, 1452 (2004).

23. See Jane S. Schacter, Lawrence v. Texas and the Fourteenth Amendment's Democratic Aspirations, 13 TEMP. POL. \& CIV. RTS. L. REV. 733, 734 (2004). 
argument was adopted by leaders within the federal branches. At the end of Part II, I explore how this account of economic liberty transformed American constitutional thought about "private" liberty. In Part III, I argue that the New Deal conception of freedom of association in the economic sphere provides the foundations for the post-Griswold construction of intimate association as an exercise of freedom.

The broader aim of this Article is thus to begin to trace the constitutional history of how the recognition and protection of freedom has focused on "non-political" forms of association. Reasoning from the image of political liberty, Americans have conceived of multiple associations where important decisions are made in mutual regard as ones where freedom is exercised, and as ones worthy of constitutional protection. The Court's decision in Obergefell signals that it is time to take account of the constitutional theory linking freedom and association that has developed beyond the political sphere.

\section{THE RISE AND FALL OF LOCHNERISM}

In this Part, I present the standard account of the rise and fall of Lochnerism in Section A. I explore both how Lochnerism is understood by scholars and how they view it as being undermined as its own premises collapsed. I provide an overview of the account of economic liberty that challenged Lochnerism in Section B in order to lay the foundations for reasoning about how the history involves not only the collapse of Lochnerism's premises but also the rise of another account of economic liberty.

\section{A. The Conventional View}

Scholarly discussion of the transformation of economic liberty during the early- to mid-twentieth century in constitutional scholarship and jurisprudence in many instances begins and ends with substantive due process. ${ }^{24}$ According to the conventional account, the foundations "of substantive due process lie in Lochnerism, which refers to the Court's expansive interpretation of due process protections for property and freedom of contract during the late nineteenth and early twentieth centuries." 25 Thereafter, Lochnerism's logic collapsed in the crisis of the New Deal, when "a face-off between the Executive and the Court in the

24. As I noted above, there are important labor law exceptions that link the labor movement to the critique of Lochnerism. Some of these exceptions contrast labor's argument with "freedom of contract" arguments. See supra note 10; see also infra note 67. This Article builds on their work and ties it more directly to post-Griswold substantive due process.

25. Robert C. Post, The Supreme Court, 2002 Term-Foreword: Fashioning the Legal Constitution: Culture, Courts, and Law, 117 HARV. L. REV. 4, 86 n.391 (2003). 
1930 s ... resulted in a repudiation of much of the substantive gloss that the Court had placed on the Due Process Clauses of the Fifth and Fourteenth Amendments." 26 Then, substantive due process was "revived after World War II, reconstituted on the seemingly solid foundation of Griswold $v$. Connecticut," but "it never lost the taint of its original connection to Lochnerism."27 Griswold marked the rebirth of substantive due process as a doctrine ascendant in cases about personal and intimate life, rather than economic ordering. ${ }^{28}$

This is a common recantation of the foundations and evolution of the battle to define economic liberty: first in Lochner, then in Lochner's demise. No reference is made, however, to Lochner's constitutional competitor. This Part identifies the ways in which the transformation of economic liberty through early employment of substantive due process is understood by scholars and the Supreme Court in order to build on that work.

\section{Its Meaning}

The central question in Lochner was whether New York State interfered with the liberty protected by the Fourteenth Amendment when it passed a law limiting the hours that bakery employees could work. The Court concluded that the legislation "interfere[d] with the right of contract between the employer and employees" and held that this right was "part of the liberty of the individual protected by the Fourteenth Amendment." 29 Adkins v. Children's Hospital of D.C. followed in this tradition, and there the Court held that to require the employers of adult women to satisfy minimum wage standards violated the freedom of contract between employer and employee ${ }^{30}$

Both cases were animated by a particular kind of constitutional argument-ethical argument-which would also be used by those challenging Lochnerism. According to Philip Bobbitt, ethical arguments are a form of "constitutional argument whose force relies on a characterization of American institutions and the role within them of the American people." ${ }^{31}$ The ethical principle of limited government, and therefore a

26. Id.

27. Id.

28. On the importance of Griswold, see Bruce Ackerman, Constitutional Politics/Constitutional Law, 99 YALE L. J. 453, 526 (1989); Lackland H. Bloom, Jr., The Legacy of Griswold, 16 OHIO N.U. L. REV. 511 1, 511, 543 (1989); William N. Eskridge, Jr., Some Effects of Identity-Based Social Movements on Constitutional Law in the Twentieth Century, $100 \mathrm{MICH}$. L. REV. 2062, 2142 (2002).

29. Lochner v. New York, 198 U.S. 45, 53 (1905).

30. 261 U.S. 525, 545-46 (1923).

31. Philip Bobbitt, Constitutional Fate: Theory of the Constitution 94 (1982). While Bobbitt focuses his initial analysis mainly on ethical arguments about limited government, he also includes those involving the idea of self-government and "inferences from the nature of republican government." Philip Bobbitt, Reflections Inspired by My Critics, 72 TEXAS. L. REV. 1869, 1937 (1994); see also PHILIP BOBBITT, CONSTITUTIONAL INTERPRETATION 64-82 (1991). I may employ this notion 
theory of negative liberty, drove the argument: the government was not to interfere with the liberty of contract, and the distributions it produced, in this private sphere. ${ }^{32}$ Lochner is thus often said, simply, to stand for laissezfaire principles in American law - that is, for the proposition that courts, and legislatures, should not interfere in market transactions. ${ }^{33}$ However, scholars of the era provide more subtle views of the case.

Robert Post places Lochner in a Taft Court era struggle to protect forms of "everyday" market ordering and the forms of economic distribution they produced against bureaucratic control. ${ }^{34} \mathrm{He}$ posits that the Taft Court's "use of substantive due process appealed to the pieties of everyday, normal life in order to resist the bureaucratic interventions authorized by [World War I]." 35 In other words, the Taft Court located freedom in everyday forms of person-to-person, atomistic market exchange and viewed state attempts to regulate such exchanges as impinging on that freedom. This was because the Court hewed to what Owen Fiss refers to as a "social contract" tradition, viewing social and economic ordering as inherently conducive to producing personal liberty, and viewing the government's power as an artificial and limited product of that social contract. ${ }^{36}$ Thus, Justice Stephen Field, who contributed greatly to the Lochnerian understanding of liberty, viewed an "economic society free from government intrusion" as one where the "forces of economic change" industrialism had unleashed could continue with "beneficial effect." 37 Employer-employee relations within the sphere of work should be beyond the reach of government, lest it interfere with the development of industrial progress. ${ }^{38}$

At the same time, the Court "used the doctrine of 'property affected with a public interest' to distinguish domains of social life that could constitutionally be subject to pervasive forms of administrative regulation

more broadly than Bobbitt would, because as Balkin notes, beyond limiting government, government may sometimes employ "the beneficial exercise" of its power in order to maintain "the public interest." Jack M. Balkin, The New Originalism and the Uses of History, 82 FORDHAM L. REV. 641, 677 (2013).

32. See BOBвITT, supra note 31 , at 230 .

33. See, e.g., GeOfFrey R. STONE ET. Al., CONSTitutional LAW 755 (5th ed. 2005) (describing scholars' "substantive" objection to Lochner as an instance of the Court having "attempted to vindicate, as a matter of constitutional law, a laissez-faire conception of the role of government that could not be sustained"); BENJAMIN TwISS, LAWYERS AND THE CONSTITUTION: HOW LAISSEZ-FAIRE CAME TO THE COURT (1942); Cass R. Sunstein, Lochner's Legacy, 87 CoLUM. L. REv 873 (1987).

34. Robert C. Post, Defending the Lifeworld: Substantive Due Process in the Taft Court Era, 78 B.U. L. REV. 1489, 1505-06 (1998).

35. Id. at 1494.

36. OWEn M. Fiss, The Troubled Beginnings of the Modern STATe, 1888-1910, 158-59 (1993); see id. at 164 ("Individuals, it was assumed would justly order their economic and social relationships through exchange; the state would be needed to enforce those bargains and create the proper conditions of exchange.").

37. Paul Kens, Justice StePhen Field: Shaping Liberty from the Gold RuSh to the GILDED AGE 4 (1997).

38. See id. 
from those domains of 'ordinary' life which could not."39 Taft's discussion of property affected with a public interest therefore began with the premise that the arrangements of the new industrial order embodied freedom as a general rule, making government restraint an exception, then proceeded to explore the exceptions that could justify a "change from the status of private business and its freedom from regulation into one in which the public have come to have an interest." ${ }^{\text {40 }}$ That is, Lochnerism stood for the proposition that freedom was embodied in the exchanges between employees and employers. The ethical norm of limited government meant that the state's power to regulate could only enter when the public had an interest, arising through the state's police power ${ }^{41}$ or because the legislation related to a legitimate national interest, such as developing utilities..$^{42}$

These accounts provide an understanding of what Lochner meant, and the type of freedom it protected, only offering exceptions against the states' police power to regulate that freedom. But the case and theory undergirding it were not uncontested. This is an insight that Victoria Nourse explores. Nourse argues that a central reason for the Court's decision in Lochner was that it viewed the New York law limiting the hours bakery workers could work as a labor law "masquerading as a health law, and thus outside the accepted categories [of constitutionally allowable legislation] of safety, health, and welfare." ${ }^{.33}$ As Nourse sees it, Lochner was embedded in a narrative of early twentieth-century resistance both to worker organization and to worker-protection laws. She sets up a Lochner-labor movement struggle by posing against Lochner a form of popular constitutionalism, in which figures such as Teddy Roosevelt argued that the law should allow for forms of labor and worker legislation that protect various forms of "social" versus "individualistic" security. ${ }^{44}$ However, she also asserts that these were

39. Post, supra note 34 , at 1494

40. Id. at 1517.

41. Victoria Nourse connects the public interest exceptions to police power. She sees Lochner as not being about "the scope of the right to contract, or even whether the right triggered a particular kind of scrutiny, but whether the state had the police power to regulate the right. If a regulation were within the police power, the case ended." Victoria F. Nourse, A Tale of Two Lochners: The Untold History of Substantive Due Process and the Idea of Fundamental Rights, 97 CAL. L. REV. 751, 762 (2009). Lochner was, under this account, not about a language of rights, which "were held by the people prior to, and not depend[ent upon], textual limitation." Id. The case, instead, was located in a conversation about the limits of state police power. Nourse's account syncs with Post's when one recognizes that when property was affected with a public interest, the state had the police power to intervene in the market arrangements that were said to embody substantive liberty.

42. Mary Cornelia Porter argues that courts used " "public interest"' doctrines to intervene into some contractual spaces-including and especially the development of public utilities, which were important to national development-but not into others. Mary Cornelia Porter, Lochner and Company: Revisionism Revisited, in LIBERTY, PROPERTY, AND GOVERNMENT: CONSTITUTIONAL INTERPRETATION BeFORE THE NEW DEAL 12 (Ellen Frankel Paul \& Howard Dickman eds., 1989).

43. Nourse, supra note 41 , at 768 .

44. Id. at 777 . 
"not doctrinal claim[s] made by professional lawyers." 45 Thus, when Roosevelt launched an attack on the Supreme Court and its protection of “"property' rights rather than 'human' rights," he argued not from doctrine, but instead from a normative political vantage that the courts were ignoring the welfare of the public. ${ }^{46}$ The critique of Lochner was therefore political at first but also came to constitute the legal understanding as Lochner was repudiated. ${ }^{47}$

Nourse shows how critique of Lochner was directed at, but not always located within, courts, and she elucidates the relationship between the Lochner decision and labor struggles. The endeavor I pursue in this Article is to continue exploring how that struggle played beyond the Progressive Era and into the New Deal. As I explain below, the architects of the New Deal had a critique of the Lochnerian conception of freedom that was not simply about human rights legislation, as was Roosevelt's, but was also about outlining a competing constitutional argument about freedom itself. Furthermore, I explore how this critique took institutional shape in legislation as Lochnerism was repudiated. ${ }^{48}$

\section{Its Repudiation}

Scholars share an understanding that the premises about economic life that undergirded Lochnerism were rejected, but their accounts tend to focus on Lochnerism's flaws rather than on a competing constitutional argument.

As a precedential matter, the repudiation of Lochner is located most frequently in West Coast Hotel Co v. Parrish, in which the Court upheld a general minimum wage law in Washington State, overruling Adkins and explicitly rejecting Lochner's conception of freedom. ${ }^{49}$ As I explain further in Part II.D, the Court there reasoned that "[1]iberty in each of its phases has its history and connotation" and explained how Lochner's conception of liberty in the workplace failed to recognize the imbalance of power between employer and employee, which undermined the liberty of the latter. ${ }^{50}$ The case therefore, as the Supreme Court would later put it, "signaled the demise of Lochner." 51

But this is not all there is to the story. For the Lochner Court, the central question was whether the police power of the state, which allowed the state to intervene on matters affecting public interest, justified the kinds of

\footnotetext{
45. Id.

46. Id. at $779-780$.

47. Id. at 792 .

48. See, e.g., JACK M. BALKIN, LIVING ORIGINALISM 88-89 (2011) (describing how lawyers translate movement claims into legal claims).

49. 300 U.S. $379,390-400$ (1937).

50. Id. at 391 .

51. Planned Parenthood of Se. Pa. v. Casey, 505 U.S. 833, 861 (1992).
} 
economic regulation at hand. The Court answered that it could not, because the activity regulated was a form of liberty protected by the Fourteenth Amendment's Due Process Clause and was beyond the state's plenary power. West Coast Hotel proceeded from the same central question. It just gave the opposite answer. That is, the Court concluded that, in light of unequal bargaining positions and the "public interest in health ... and protection" of the employee from the abuses that come from such power imbalances, ${ }^{52}$ the wage legislation was a "reasonable exercise of the police power of the state." 53

As a historical matter, scholars thus see the demise of Lochner in the undermining of its premises about of freedom as existing inherently in industrial revolution era economic life. The doctrine "collapsed with the growing awareness that the impersonal kind of contractual 'selfgovernment' that great inequalities of wealth and bargaining power too often generated was government of, by, and for the more powerful partya mockery, more than a model, of the democratic self-government to which the ideal spoke." ${ }^{54}$

There is an unanswered question, though: If the form of self-government that Lochner embodied was a "mockery, more than a model" of democratic self-government, was there a form of self-government that could be an expression of freedom in the workplace? This is the question answered by the New Deal.

\section{B. Beyond the Conventional View}

Lochnerism was part of a Progressive-era debate over the meaning of the Constitution's guarantee of liberty in the economic sphere in a nation composed largely of wage-earning workers. That debate came to a head in the New Deal, when another argument about a form of economic liberty that was deserving of constitutional protection came to the center of American discourse. To move beyond the conventional narrative, I lay out in this section the premises and arguments undergirding this side of the debate.

\section{A Balance Offset}

One remarkable aspect of the conventional narrative is the extent to which Lochnerism is premised on a notion of continuity rather than on a frank

52. Id. at 585 .

53. Id. at 581

54. Tribe, supra note 21, at 1939 (2004). Bruce Ackerman similarly sees Lochner's premises transformed, in this case by a constitutional engagement between the Executive and the Court, where FDR, proceeding under a model of presidential leadership, won the support of the American people for the understanding that the national government could intervene into the economic sphere and assert an activist, national state. See ACKERMAN, supra note 12, at 280-83. 
confrontation with just how much economic ordering had changed in the nation after the Civil War. For the New Deal architects, the changes brought by both the Industrial Revolution and the transition from an agrarian republic to a system of wage-earning workers were constitutionally significant. They undermined the conception of economic liberty upon which our constitutional political economy was based, replacing a system premised on independent agrarian entrepreneurs possessing liberty with one where citizens were workers in enterprises without adequate or equal bargaining power with their employers, such that the conditions of everyday exchange embodied domination more so than liberty. Indeed, for the New Deal architects, the conditions of economic life threatened to throw off the entire constitutional system balance between economic and political liberty. To understand how the New Deal architects came to adopt a competing, affirmative view of economic liberty, one must first understand their diagnosis of why and how economic liberty did not exist in the modern workplace, and why this was an issue of constitutional proportions.

Since the Revolution, it had been "axiomatic" in American constitutional thought that political freedom required economic freedom. ${ }^{55}$ Economic freedom was thought to be achieved by granting wide access to property, which was thought in turn to make possible a system of citizenentrepreneurs - then, white males-whose self-sufficiency would make them the kinds of independent persons that citizenship in the republic demanded..$^{56}$ This notion was not only linked to property enabling citizens to become entrepreneurs or farmers, but also, and equally importantly, to combating docility and domination in economic life that would bleed into politics. ${ }^{57}$ Economic liberty therefore supported and made possible political liberty. The two were symbiotic.

For the labor movement, the concentration of employer power as the nation moved from an agrarian system to an industrial system based on wage-earning created the very webs of dependence that property was meant to untangle. Thus, as the nation became "a country of hired men," this notion of atomistic and self-sufficient citizen-entrepreneurs could not

55. ERIC Foner, The StORY OF AMERICAN FreEdom 9 (1996); see also RoBert DaHL, A PREFACE TO ECONOMIC DEMOCRACY 1 (1986) ("Within a generation or so after the Constitutional Convention, a rough consensus appears to have been reached among Americans-among white male citizens, at any rate - that a well-ordered society would require at least three things: political equality, political liberty, and economic liberty....").

56. See FONER, supra note 55, at 9.

57. See, e.g., GORDON WOOD, THE RADICALISM OF THE AMERICAN REVOLUTION 106 (1998) ("“If virtue was based on liberty and independence,' then it followed that only autonomous individuals free from any ties or interest and paid by no master were qualified to be citizens. Jefferson and many other republican idealists hoped that all ordinary yeoman farmers who owned their own land and who depended for subsistence only on 'their own soil and industry' and not 'on the casualties and caprice of customers' would be independent and free enough of pecuniary temptations and marketplace interests to be virtuous."). 
persist, if ever it could have before. ${ }^{58}$ The change, as Robert Dahl puts it, was meaningful:

The older vision of a citizen body of free farmers among whom an equality of resources seemed altogether possible, perhaps inevitable, no longer fitted that reality of the new economic order in which economic enterprises automatically generated inequalities among citizens: in wealth, income, social standing, education, knowledge, occupational prestige and authority, and many other resources..$^{59}$

The New Deal architects therefore argued that economic conditionswhere workers had little control over their hours and pay, ${ }^{60}$ where child labor existed ${ }^{61}$ and where efforts of worker to associate to challenge the conditions were thwarted ${ }^{62}$ - undermined the liberty of citizens. A salient image of this was the mill village: a system where workers were sometimes hired as families, worked incredibly long hours without adequate pay, and lived on company grounds and often company credit. ${ }^{63}$ As William Forbath puts it, the "increasing concentration of ownership of resources and capital" had factory workers "competing against new machines and new unskilled and underpaid workers," during a time that would "dispossess[] artisans and new immigrants and their families [along with] millions of working-class women and children into the factories." $"$ "The proprietors of these factories "demand[ed] longer and longer hours of 'mindless toil,' that deprived workingmen of the time to educate themselves and participate in public affairs." 65 The system produced more "dependence, ignorance, and more grinding poverty." 66 In this way, it disrupted the entire constitutional political economy.

The notion that such a system could maintain economic independence

58. See, e.g., Christopher L. TOMLins, THE State AND THE Unions: LABOr RElations, LaW, AND THE ORGANIZED LABOR MOVEMENT IN AMERICA, 1880-1960, ch. 5 (1985) (describing how journeymen and trade associations in the 1800 s believed that worker combination was necessary in an economy that defied the image of an agrarian republic and that these associations were the axis of republican society).

59. DAHL, supra note 55 , at 3 .

60. See, e.g., LANDON R.Y. STORRS: CIVILIzING CAPITALISM: THE NATIONAL CONSUMERS' LEAGUe, WOMEN's ACTIVISM, AND LABOR STANDARdS IN THE NEW DEAL ERA ch. 1 (2000) (exploring the fight for minimum wage and hour laws); George E. PAUlsen, A Living WAGE FOR THE FORGOTTEN MAN: THE QUEST FOR FAIR LABOR STANDARDS 1933-41, 16-34 (exploring workers' difficulties in controlling wages and hours and in receiving legislative aid in doing so).

61. See, e.g., Florence Kelley, SOME EthiCAl Gains Through LEgiSlation ch. 1 (1910) (exploring the phenomenon of child labor in the United States).

62. See, e.g., Felix FrankfurTER \& NATHAN GREENE, THE LABOR INJUNCTION (1930) (exploring how courts used injunctions to impede workers from organizing).

63. See, e.g., IRVING BERNSTEIN, THE LEAN YEARS: A HISTORY OF THE AMERICAN WORKER, 1920-1933, chs. 1 \& 2 (1960) (exploring how in the years before the New Deal, workers were thwarted from bargaining collectively and surveying the conditions in mill villages).

64. William E. Forbath, Caste, Class, and Equal Citizenship, 98 MICH. L. REv. 1, 28-29 (1999).

65. Id. at 29.

66. Id. (internal quotation marks omitted). 
and freedom rang false for the architects of the New Deal order. They endeavored to challenge the arrangement and regulation of economic life in America as it had evolved with industrialism, arguing that it was antithetical to, rather than an embodiment of, liberty; that it created conditions of industrial insecurity and worker incapacity under the guise of liberty and equal contract rather than allowing worker association to flourish in a manner that might give workers some agency over their hours, pay, and conditions, thereby restoring to them the ability to be the types of persons that constitutional citizenship demanded. ${ }^{67}$ These actors thus asked how the nation's central constitutional commitments could be employed to reshape the economic sphere in order to maintain the constitutional balance between political and economic liberty. ${ }^{68}$ As economic life increasingly looked like a complex social domain where decision-making was made and where domination was possible without coordination-more and more like political self-government-these architects turned to political life for an analogy.

\section{The Argument}

In order to make the case for a changed view of economic liberty for a changed economic order, the New Deal architects made constitutional claims against those associated with Lochnerism. They made two complementary arguments that I briefly present at a general level in this section before turning to the history of the development of those arguments below. ${ }^{69}$

67. For an overview of labor struggles during this transition, see generally FONER, supra note 55, 130-46 (1996) (tracing how the labor movement came to make freedom of association arguments about worker organizing); William E. Forbath, Caste, Class, and Equal Citizenship, 98 MICH. L. REv. 1, 2630, 58-61 (1999) (overviewing labor's arguments from the First, Thirteenth and Fourteenth Amendments about worker association and its arguments about industrial freedom rather than control); James Gray Pope, Labor's Constitution of Freedom, 106 YALE L. J. 941, 962-966 (1997) (exploring how labor's "constitution of freedom" posed worker association against industrial servitude); James Gray Pope, The Thirteenth Amendment Versus the Commerce Clause: Labor and the Shaping of the Post-New Deal Constitutional Order, 1921-1950, 102 COLUM. L. REV. 1, 15-25 (2002) (same); see also TOMLINS, supra note 58 , at $34-44$ (explaining the labor movement's argument about unions as the axis of republican society).

68. The move of reasoning from political liberty towards an account of economic liberty is not novel. Theorists from Dewey to Dahl have argued that economic institutions should be congruent with political ones. See DAHL, supra note 55 (arguing for the end of corporate capitalism and for the beginning of collective capitalism, which would be more true to democratic values and requirements); JoHN DEWEY, The PuBliC AND ITS PROBLEMS (1927) (arguing that democracy must be a way of life that entails participation in the governance of all institutions of one's life). And theorists from Tocqueville to Mill have argued that citizen association in private life can produce democratic practices. See 1 ALEXIS DE TOCQUEVILLE, DEMOCRACY IN AMERICA 68 (Arthur Goldhammer ed. \& trans., The Library of America 2004) (1835) (arguing that associations and mediating groups of governance act as schools of democracy); JOHN STUART MILL, THE PRINCIPLES OF POLITICAL ECONOMY WITH SOME OF THEIR APPLICATIONS TO SOCIAL PHILOSOPHY (1848) (arguing that forms of workplace democracy would allow workers to cultivate democratic capacities more broadly).

69. See infra Part II.b. 
Like the constitutional argument associated with Lochnerism, labor's argument was an ethical one. But it was an ethical argument based on the meaning of self-government as national ethos rather than on limited government. Labor argued that the nation's core constitutional commitment to self-government mandated that the Constitution protect both political liberty, which had been defined as associative participation in political selfgovernment, ${ }^{70}$ and economic liberty, which labor and its allies defined as associative participation in worker self-government in labor unions. ${ }^{71}$ Indeed, they argued that worker self-government was not only consonant with the nation's ethos but also was necessary for workers to become the kinds of economically un-dominated people that citizenship in the republic demanded. When workers formed in a union to deliberate on their shared goals and ends, they engaged in a democratic act and expression of freedom in everyday life. ${ }^{72}$ Thus, for example, when the Senate Report for the NLRA stated that "[a] worker in the field of industry, like a citizen in the field of government," has "an inherent right" to "self-government," it was making a claim about how the constitutional ethos of self-government structures not

70. As historian Eric Foner puts it, describing the early American conception of freedom, "Political freedom for men meant the right to self-government, the power to consent to the individuals and political arrangements that ruled over them." ERIC FONER, supra note 55, at xvi. Political liberty was fundamentally defined by the "right to participate" in the community's "political self-determination. Id. at xvii. Freedom was therefore "both an idea and a practice." Id. Similarly, Gordon Wood, in his sweeping The Creation of the American Republic, contrasts "public or political liberty," which is the "right of the people to share in the government" through participation in self-government with "personal or private liberty," which spoke to the "protection of individual rights against all government encroachment." GORDON S. WOOD, THE CREATION OF THE AMERICAN REPUBLIC 608-09 (1968). Alexis de Tocqueville picks up on this notion of political freedom as something exercised by the community, speaking of the "apprenticeship of freedom" and calling freedom a "noble exercise of the faculties of man." TOCQUEVILLE, supra note 68, at 243. Philosopher Quentin Skinner explores a republican tradition spanning back to Roman moral philosophy that "connects freedom with self-government," marking a notion of political freedom that is distinct from, but also contributes to, "the enjoyment of personal liberty." Quentin Skinner, The Paradoxes of Political Liberty, in THE TANNER LECTURES ON HUMAN VALUES 229 (McMurrin, S. M., ed., 1986). Skinner explains that political freedom is exercised in a "community ... in which the will of the citizens, the general will of the body-politic, chooses and determines whatever ends are pursued by the community as a whole." Id. at 239

71. See Richard Michael Fischl, 'Running the Government Like a Business': Wisconsin and the Assault on Workplace Democracy, 121 YALE L. J. ONLINE 39, 40 (2011) (discussing "the struggle between democratic governance and authoritarian control in the American workplace"); see also Fishkin \& Forbath, supra note 9, at 690 ("Social and economic citizenship were simply inseparable from political citizenship, and the government had 'inescapable obligations' to protect both.").

72. Unions are, admittedly, a weaker form of self-government than the purely political one at the center of the constitutional order. Unions offer representation-through, for example, elections-but lack other important political features such as equal protection and due process guarantees. See, e.g., CYNTHIA ESTLUND, REGOVERNING THE WORKPLACE: FROM SELF-REGULATION TO CO-REGULATION 28-29(2010).

72. See BRUCE ACKERMAN, 1 WE THE PEOPLE: Foundations 20 (1991). The AFL during the time studied here did not take its claims to what could be conceived of as their logical end: an argument for worker ownership of industry. This fact reflects, among other things, a compromise between property law and corporate law as they had developed and a workable labor law. See FONER, supra note 55, at 135 (the rise of the AFL "reflected a shift toward the judgment that workers must frankly accept their status as wage earners and seek higher wages and better working conditions" through collective bargaining). 
only political but also economic ordering ${ }^{73}$ One could also call it a purposive argument because it drew on how the nation must act to effectuate to fulfill the purposes of the constitutional system ${ }^{74}$-that is, to make the norm of self-government real in the lives of citizens who were now mostly wage-earning workers. ${ }^{75}$

The New Deal architects would at times make this strong claim that the ethical commitment to self-government encompassed worker selfgovernment, and at other times, make a complementary but somewhat weaker claim about constitutional inference. The move was to argue that it would be incoherent to have a constitutional commitment to political selfgovernment yet impede workers from participating in economic selfgovernment. ${ }^{76}$ Put another way, even if the political commitment did not encompass the economic commitment, labor argued that it would be incoherent and incongruous to protect political liberty defined as participation in self-government and deny economic liberty defined as participation in worker self-government. Indeed, the protection of worker self-government was especially important in the industrial order where worker association was critical to defining the governance regime at work and, therefore, affected the daily freedom of citizens. ${ }^{77}$

As I explore below, labor made these arguments at various points, though ultimately they were made by labor, Congress, and FDR, who used them to justify the growth a national regulatory regime to fulfill these constitutional purposes. ${ }^{78}$ Along the way, these actors would pierce the shield of negative liberty that had defined the American commitment to freedom in spheres beyond politics-and that was employed by the forces behind Lochnerism - and redefine economic freedom around association. These twin moves of reasoning beyond negative liberty in spheres beyond politics and reasoning about liberty there in terms of association and exercise would,

73. See infra note 127 and accompanying text.

74. Balkin offers an account of an argument from purpose - that is, "the purpose or principles behind the Constitution"- and identifies "republicanism" and "self-government" as animating purposes. Balkin, supra note 31 , at 660 .

75. See supra note 12 and accompanying text.

76. See infra Part Il.b.

77. Just as the Founders had assumed an agrarian order and justified property rights in part because they thought of economic independence as a precondition to republican constitutional self-government, see infra Part II.A., the AFL and its allies eventually assumed an industrial order and argued that labor freedom was a precondition of republican constitutional self-government. For one, worker selfgovernment could protect workers from the abuses of industry such as low wages, intolerable conditions, and domination in the mill village. Whereas, without protection against such abuses, workers would become the very kind of docile and economically-dependent citizens incompatible with the ideal of republican self-government. Thus, where property was the key to economic independence and freedom at Founding, balancing property with worker self-government became the key during the New Deal era.

78. These were rights to be enacted and protected by government against actors in the private sphere-a proposition supported in part by the fact that the institutions of private life had become so powerful, interdependent, and complex that they might interfere with the functioning of republican selfgovernment. See, e.g., Forbath, supra note 10, at 176. 
contrary to the conventional narrative, be an intellectual precursor to the connection of another form of "non-political" association with freedom in the formulation of substantive due process jurisprudence later in the twentieth and twenty-first centuries.

\section{A REAPPRAISAL: THE NEW DEAL TRANSFORMATION}

This Part explores how the competing argument about economic liberty was developed by the labor movement, was translated by Congress into legislation, promoted by the Executive, and adopted by the Supreme Court. The Part ends by drawing these disparate strands together and presenting an account of how the New Deal architects both redefined economic liberty around worker association in an affront to Lochnerism and struck a blow against the old way of viewing liberty in private spheres solely in terms of governmental non-interference.

\section{A. Labor}

This section explains how the AFL and its presidents drew out a constitutional argument as they fought for union recognition and, ultimately, legislative protection. This argument became clear just after the turn of the century, when the AFL had consolidated its power, and found a powerful leader in Samuel Gompers. Gompers presided over the AFL in the years when unions were still struggling for recognition, often fighting courts and hostile legislatures, and he delivered his message about liberty in worker association-connecting political freedom in self-government to worker freedom in union self-organization-with particular urgency. ${ }^{79}$ As I explore below, Gompers began by connecting worker freedom to political freedom in fits and starts before developing a stronger and more coherent approach to reasoning about and arguing for economic liberty.

\section{The Gompers era}

In 1914, Gompers and the AFL were fighting against courts that stood in the way of labor association by holding that combinations of workers violated antitrust law. ${ }^{80} \mathrm{He}$ helped to shepherd in the Clayton Antitrust

79. My concern here is less on the AFL's aims at the time and more on its language. It should be noted both that the labor movement was not focused on a national policy like the NLRA at the time (although it would be later), and that this summary is hardly comprehensive of labor's argument. For example, there is a rich history of the labor movement arguing for collective bargaining rights under the 13th Amendment, and of it resisting state assistance and legislative efforts. See e.g., Forbath, supra note 10, at 183-85; James Gray Pope, The Thirteenth Amendment Versus the Commerce Clause: Labor and the Shaping of the Post-New Deal Constitutional Order, 1921-1950, 102 COLUM. L. REv. I (2002); James Gray Pope, Labor's Constitution of Freedom, 106 YALE L. J. 941 (1997); see also CHRISTOPHER L. TOMLINS, THE STATE AND THE UNIONS: LABOR RELATIONS, LAW, AND THE ORGANIZED LABOR MOVEMENT IN AMERICA, 1880-1960 (1985).

80. See, e.g., FRANKFURTER \& GREENE, supra note 62. 
Act, ${ }^{81}$ which exempted unions from antitrust regulation on the theory that the labor of a human being is not a commodity to be traded in commerce. Along the way, Gompers strove to tie worker association not to anticompetitive conduct, subject to antitrust law, but to the promise of selfgovernment implicit in the Constitution. For Gompers, self-government was not merely confined to political association and political liberty but was deeply related to the economic realm as well.

Gompers began to foreshadow the constitutional argument by connecting political freedom to industrial conditions. At an AFL gathering in 1914, Gompers said, "We profess to believe in democratic freedom yet domination of power so ruthlessly prevails in industry." 82 The notion that the relationships of industry, rather than embodying liberty, as the Taft Court would have it, represented its opposite, provided an important critique, and the connection of democratic freedom-typically conceived in political terms - with the conditions of industry was an important hook. The AFL convention met in Philadelphia in the same year and Gompers continued to link union association to political liberty. Gompers stated that Philadelphia was where "the charter of America's freedom and independence was declared to the world." 83 The meeting in Philadelphia had been a "development of the spirit of organized working people," a spirit that was "in harmony with the Declaration of Independence" which gave to the nation "a new concept of the rights of man." Gompers declared that the "mission of the American Federation of Labor" was to "translate these declarations into the everyday activities of the lives of our people." 85

By 1919 , so prevalent was the connection between the American ideal of freedom and worker association that it took center stage in a collection of Gompers's writing and speeches. In the introduction to Gompers's Labor and the Common Welfare, Hayes Robbins, who wrote on labor issues, stated that "self-government," the central ideal of the constitutional order, was not only the central ideal of the AFL and labor movement, but that labor association in unions was an exercise of "freedom, under self-control of democracy" and that such a "power of self-control, right in the heart of the labor problem itself, is what most re-assures those who see the future of democracy as mainly an industrial issue." 86 Robbins thus argued that worker

\footnotetext{
81. Clayton Antitrust Act of 1914, 15 U.S.C. $\S \S 12-27$ (2006).

82. Samuel Gompers, Editorial, AM. FEDERATIONIST, December 1914, at 1081.

83. Samuel Gompers, President, AFL, Address to the AFL Convention at Horticulture Hall, Philadelphia, PA (November 9, 1914).

84. Id.

85. $I d$.

86. Hayes Robbins, Introduction to SAMUEL GOMPERS, LABOR AND THE COMMON WELFARE, at $\mathrm{v}$ (1919)
} 
association was an exercise of freedom and self-government. Selfgovernment was not merely a fundamental ethic of the nation in politics; it was one that regulated economic life.

In the volume, Gompers stated that it is the "liberty implied in the fundamental principles of our Republic" that demanded that workers associate in unions. ${ }^{87}$ At another point, Gompers asserted, "I take it, my friends, that it would be part of wisdom if those who loved liberty most and stood for the principles upon which the republic of our country is based, would realize that in the labor movement of our time is vested the power and the spirit to defend justice and to perpetuate free institutions." 88 The struggle for worker self-government involved "the very essentials of free institutions." 89 Gompers drew on the core purposes of the constitutional system to make claims about economic governance. At other points, Gompers claimed that those opposed to worker association in unions denied workers the proper extension of the "fundamental principles of freedom." He stated that the "institutions of the United States represent a principlethe great principle of self-government" that was realized by associations of workers engaged in self-representation and self-organization. ${ }^{91}$ Selfgovernment, then, was a constitutional super-norm-our constitutional ethos-and as such it needed to extend from politics into the industrial world.

The labor movement was not alone in making these arguments. Labor had an ally in Louis D. Brandeis, whom President Wilson had nominated to the Supreme Court in 1916 and who had through legal argument come to these conclusions himself. Brandeis, as counsel for states trying to implement workers' laws, wrote compelling amicus briefs including one in the wellknown Muller $v$. Oregon, ${ }^{92}$ a case involving limitations on the hours that women could work. These were, as historian Eric Foner put it, "revolutionary social and economic briefs." ${ }^{93}$ And Brandeis wrote in support of labor rights in both his roles as a citizen-lawyer and later as a Supreme Court Justice. As Foner aptly summarizes, Brandeis "maintained that unions embodied an essential principle of associational freedom-the right of people to govern themselves." ${ }^{\prime 94}$ Brandeis asserted that citizens could not be "self-respecting members of a democracy" without "freedom

87. SAMUEL GOMPERS, LABOR AND THE COMMON WELFARE 60 (1919).

88. Id. at 157 (quoting Samuel Gompers, President, AFL, Address at Chicago, Ill., 1908).

89. Id.

90. Id. at 158 .

91. Id. at 211 (quoting Samuel Gompers, President, AFL, Annual Report to AFL Convention, Kansas City, December 1898).

92. 208 U.S. $412(1908)$.

93. IRVING BERNSTEIN, THE LEAN YEARS, A HISTORY OF THE AMERICAN WORKER, 1920-1933, at $223(1969)$

94. FONER, supra note 55, at 142 
in things industrial."95 There could not coherently be "political liberty" alongside "industrial slavery." "96 Thus one can see ethical and purposive arguments alive in Brandeis's thought: the ethic of our constitution was one of self-government, and self-government needed to extend from the political to the economic; and the Constitution's purpose of effectuating self-government was thwarted by denying workers freedom of association, without which they could not become self-respecting members of a democracy.

World War I provided the labor movement a platform to assert that associations of workers engaged in self-organization embodied freedom. The AFL produced and ratified a statement in response to both the War and to the democratic struggles commenced by it. The union said that the War had caused a "world-wide determination to overthrow and eradicate all autocratic institutions, so that a full measure of freedom and justice can be established." 97 The War "awakened more fully the consciousness that the principles of democracy should regulate the relationship of men in all their activities." justice and opportunity... to be applied."99 The AFL thus used the experiences of the War to build an argument about how a new concept of liberty should extend beyond the political, into "all of the activities of men," chief among them the associative activities of workers. ${ }^{100}$ For the AFL, it was as "inconceivable that workers as free citizens should remain under autocratically made law within industry and commerce as it is that the nation could remain a democracy while certain individuals or groups exercise autocratic powers." 101 That is, they argued, it was inconceivable to have a political conception of self-government as an expression of freedom without extending it to the sphere of work, which was so central to the daily lives of most Americans. Self-government, as our constitutional ethos, needed to structure both realms.

\section{Green and the New Deal}

The Depression, and the advent of the New Deal, would provide a new platform from which to make the argument about associative freedom in the workplace, as well as new supporters.

William Green was now at the AFL's mast and the labor movement had

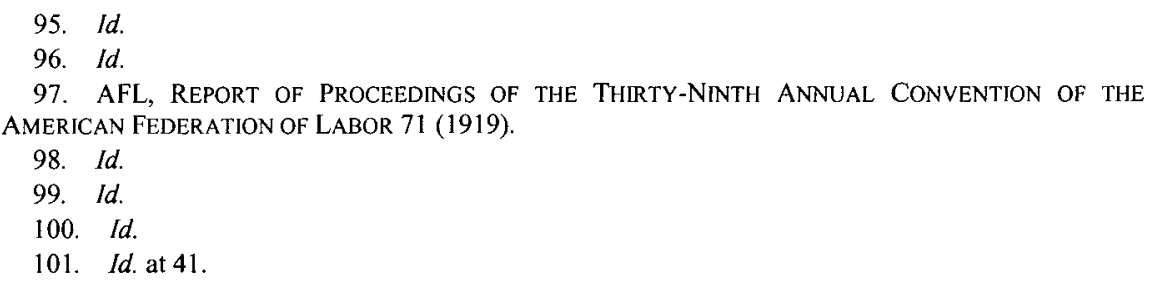


renewed energy with the election of FDR. During this time, Congress passed the National Industrial Recovery Act (the "Recovery Act"), 102 and, two years later, the NLRA. The Recovery Act produced a system of sectorbased codes, under which industries would commit to both recognizing unions and to norms about workplace conditions and contracts. The Recovery Act, however, was a corporatist half-measure that would ultimately fail to protect the right of workers to bargain collectively: employers either ignored its collective bargaining guarantees or interpreted the guarantees to allow the employers to create and direct their own "company unions." Both courses of conduct, of course, sapped collective bargaining of its power. ${ }^{103}$ The labor movement thus pushed for the NLRA, which more firmly guaranteed workers the right to bargain collectively and entrenched formalized procedures to ensure this right was protected. ${ }^{104}$ Along the way, Green took up the conception of liberty that would challenge the one adopted in Lochner with the same flourish as Gompers.

As the AFL moved toward supporting federal protection of the right to bargain collectively, Green strove to center labor in both American political life and democratic thought. On the heels of the passage of the Recovery Act, he wrote to his movement that labor's struggles in association were "in deciding matters that concern our living" that are "of fundamental importance to each of us." $105 \mathrm{He}$ then connected the struggle for worker association to the American struggle for democracy. He spoke of the quest for freedom and self-government during the Revolution, saying that political self-government was "adequate to meet our needs" then, but as "economic and social structure became more interdependent and complicated," we found that political lawmaking "was only a small part of government and affected only a limited group of decisions that affected our daily living." $106 \mathrm{He}$ then made the argument that worker association in industry could provide for that necessary self-governance. ${ }^{107}$ As he put it at another point, union association was the mechanism for "working out ... the principles of freedom and democracy in this new field of

102. Pub. L. 73-90, 48 Stat. 195 , enacted June 16, 1933, codified at 15 U.S.C. $\$ 703$. The AFL had actually written and backed an hour and wage law, the Black Bill, in 1932, but FDR intervened and pushed for the Recovery Act as a compromise measure. The AFL accepted the measure on the condition that, among other things, section 7(a), which it had written, would be added to ensure worker collective bargaining guarantees. See IRVING BERNSTEIN, THE TURBULENT YEARS: A HISTORY OF THE AMERICAN WORKER 1933-1941 24-30 (1969).

103. See generally IRVING BERNSTEIN, THE NEw DEAL COLleCtive BARGaINING POLICY ch. 3 (1950).

104. See Forbath, supra note 10, for an exploration of how progressive labor leaders moved away from 13th Amendment-based arguments in favor of labor protection and towards favoring a national legislative enactment based on the Commerce Clause.

105. William Green, Editorial, AM. FEDERATIONIST, March 1933, at 231.

106. Id.

107. Id. 
government."108 In these instances and more, Green was conceiving of liberty as participation in self-government, and arguing that such liberty ought to extend to workers as well as their associations too reflect an economic form of self-government. ${ }^{109}$ If self-government was the nation's ethic, and if making it real in the lives of citizens was the Constitution's purpose, then workers needed their rights of association to be protected.

Green and the AFL were hardly alone. In 1931, a member of the Brotherhood of Railway clerks wrote, "Mere political independence was a dead letter unless it was accompanied by industrial independence." 110 This was a purposive argument about constitutional political economy: the political dimensions of self-government which are at the center of our constitutional system are thwarted without allowing industrial freedom. Intellectuals, too, joined in. Edward Devine wrote in his 1933 book, Progressive Social Action, that where a constitutional system dedicated to political democracy remained, "industrial democracy is certainly conspicuous for its absence."111 One of the most coherent and comprehensive academic treatments of this argument was taken up by Professors Ordway Tead and Henry C. Metcalf in their book Labor Relations under the Recovery Act, published in 1933. The passage of the Recovery Act prompted their book, which sought to justify further the Act's protection of collective bargaining rights. They argued that "[a]t bottom the problem is one of the worker's relation to industry in a democratic country where the principles of representative government are rightly held to be fundamental to the preservation of all institutions which are to serve all the people."112 They thus argued that the constitutional norm of self-

108. William Green, Editorial, AM. FEDERATIONIST, March 1935, at 243.

109. At other times, the democratic feature of union organization was touted without explicit reference to freedom. Continuing to link democratic freedom to worker self-government, in 1931, Green wrote that the workplace was a "field of personal relations" in which "democratic practices must be incorporated" by allowing for worker self-government. William Green, Editorial, AM. FEDERATIONIST, November 1931, at 1331. In 1933, the American Federationist included an article by labor historian George Douglas, which asserted that labor's "troubles do not arise from the failure of democracy, but rather because democracy has never been accorded an honest opportunity to fully and properly function." George Douglas, The Question, AM. FEDERATIONIST, January 1933, at 62. And so, the labor movement should direct its attention toward democracy's "perfection" in the workplace. Id. The movement represented the best hope for that perfection, because its ideals embodied "the practical application of the spirit and principles of the democratic concept of social organization, economic as well as political." Id. Douglas warned, "Our whole problem is that of putting the principles of democracy into positive practice in our workday lives and affairs, and so long as we suffer defeat of this latter purpose we [cannot] enjoy the full benefits of a true democracy." Id.

110. Henry F. Kirkham, Union Achievements, AM. FEDERATIONIST, August 1931, at 948.

111. Edward T. DeVINe, Progressive SOCIAL ACTION 55-56 (1933). He continued that in democratic societies "the important thing for [workers] is not the vote which they cast once a year at the polls, but what happens to them in the places where they work. Id. at 56 . There becomes for them a sense of the "absurd disparity between their assumed importance as voters when a political campaign is in progress and their helpless insignificance as members of the economic order." Id.

112. ORDWAY TEAD \& HENRY C. METCALF, LABOR RELATIONS UNDER THE RECOVERY ACT 165 (1933). Later in the book, Tead and Metcalf took on the evolution of democracy and argued that a long 
government in economic life was realized in worker association. Justifying union organization, they asserted an "essential unity of aim and pattern which must underlie all our communal efforts, including the economic because of its crucial and determining importance."113 The sooner that this is realized, the sooner "shall we all work to create a genuine selfgovernment in industry." 114

Perhaps most important was the extent to which and the ways in which Green took up these arguments as the labor movement agitated for the passage of the NLRA. In 1934, it was clear that the Recovery Act had no teeth. So when the NLRA had its first real chance of passage, Green argued in a speech in Akron, Ohio, "In a democracy such as ours it is but proper and right that we should extend the principles of democracy, not only in government but in industry." 15 That year he also argued that labor was the "defender of American institutions and American self-government" and that the "salvation of labor lies in democracy."116 In 1935, he argued that "upon the character of these work relationships will rest the real measure of selfgovernment in the United States." 17 Labor's consistent move therefore was to anchor political and economic liberty around self-government, and to espouse a vision of economic liberty centered on union association as an embodiment of worker self-government.

Although these movement actors did not condemn Lochnerism by name, ${ }^{118}$ they worked against its internal logic. They offered ethical and purposive arguments about what the constitutional commitment to "freedom as self-government" meant and required, connecting worker association to economic liberty. While the Taft Court's "use of substantive due process appealed to the pieties of everyday, normal life"119 in defining freedom, these movement actors argued that the conditions of interaction within the industrial sphere did not make liberty possible. They saw that zone of work-life as one where contracting was unbalanced and hardly represented a process of willful deliberation between employers and

human experience with preservation of individual rights and concentrations of power that thwarted it led to the conclusion that "in the long run, people have to protect themselves and govern themselves, if their own wishes and aspirations are to be realized." Id. at 224. They argued that this conclusion extends not only to politics but to economic systems, and said that "our economic life has to be governed; and the purpose of such government no less than its general methods have to harmonize with that purpose already established as sound in political government." Id. at 226.

113. Id. at 228 .

114. Id.

115. William Green, President, AFL, Address at Akron, Ohio (November 24, 1934).

116. William Green, Speech (d. 1934), in William Green Papers, Yale University, New Haven, CT, box 18 .

117. William Green, Editorial, AM. FEdERATIONIST, March 1935, at 242.

118. See Greene, The Anticanon, supra note 1, for an account of how Lochner came to stand in as the representative of this conception of freedom.

119. Post, supra note 34 , at 1494. 
employees; it was one where our foundational constitutional commitments to self-government and democratic life were weak. They located freedom in the association between workers, which was for them an exercise of freedom that, though not the self-government of our democratic order in the political realm, was an image in work-life, and a bulwark against unbalanced workplace power. Thus while, as Post recognizes, the "Taft Court ... never articulated why constitutional value ought to attach to the expectations of everyday [economic] life," 20 these actors were telling a different story about what everyday life looked like and how the nation's core constitutional commitment to self-government would be fleshed out best in economic life.

The question is whether this conception of freedom would be adopted beyond the labor movement and intellectuals. It is to this question of translation that the next sections turn.

\section{B. Congress}

Senator Robert Wagner of New York, who had long focused on and struggled for workers' rights, ${ }^{121}$ was a driving force behind a national labor law. In 1934, Wagner believed that the nation's labor movement and commitment to workers was strong enough to push for a signature legislative enactment. The path had been cleared a bit with piecemeal enactments. For example, as mentioned above, Congress had just recently passed the Recovery Act, which attempted to place the nation's industries under codes of conduct and theoretically, in section 7(a), provided workers the right to bargain collectively. But the Recovery Act was flouted by employers, ${ }^{122}$ and Wagner knew that a stronger bill — establishing not only the right of workers to bargain collectively but also firmer institutional mechanisms to ensure that right-was needed. He therefore proposed the NLRA and placed center-stage the labor movement's ethical and purposive arguments about worker association and self-government. ${ }^{123}$

The consideration of the bill was kicked off in 1934 when Senator Copeland placed in the record an article that Senator Wagner had penned in The New York Times in support of the bill. In the article, Wagner asserted that "major questions of self-expression and democracy are involved" in the

120. Id. at 1530 .

121. See, e.g., J. JosePh Hutchmacher, Robert F. WAGNER AND thE Rise of Urban LIBERALISM 3-38 (1968).

122. See ARThur M. SChlesinger, JR., The Coming of the New DeAL 137-45 (1958) (explaining how employers put pressure on employees and set up company unions, which prohibited workers from joining with other unions or workers from other employers, sapping collective bargaining of its power).

123. For all fuller history of the legislative struggles and of Wagner's vision of freedom, and of the sampling of different arguments made, see Barenberg, supra note 10; and Forbath, supra note 10. 
ability of workers to be free to associate in unions. ${ }^{124} \mathrm{He}$ continued that at "a time when politics is becoming impersonalized and the average worker is remote from the processes of government, it is more imperative than ever before that industry should afford him real opportunities to participate in the determination of economic issues." 125 Wagner was therefore setting up a relationship between political self-government and economic selfgovernment. Wagner continued on to make clear that it was our democratic commitments_- "our most cherished ideals"126 - that mandated recognition and protection of this associational freedom.

The Senate Report would strengthen the link, construing worker association as an important aspect of constitutional freedom. Worker selfgovernment, the Senate Report that came out of the committee hearings declared, simply attempted to be true to "rights that were inherent in citizenship," including the right "to be free to form or join organizations, to designate representatives, and to engage in concerted activities." 127 That is, the Senate Report drew from political association towards worker association, linking political citizenship and economic self-determination. Speaking of the disenfranchisement of the "citizen-worker" who could not form unions together with fellow employees to secure bargaining power and participate in workplace democracy, the Report continued, "[a] worker in the field of industry, like a citizen in the field of government," has "an inherent right" to "self-government." 128 This was an important form of ethical argument: we as a nation are committed to self-government and that commitment stretches beyond the confines of politics.

However, the debate would not go far during 1934 . The Senate ultimately ended its session without passing the NLRA, as FDR intervened with a measure to strengthen the Recovery Act. What followed was the "volcanic summer of 1934," when workers across the country protested and went on strike in the name of what they saw as the right to bargain collectively. ${ }^{129} \mathrm{As}$ labor historian Irving Bernstein told it, "In 1934 anybody struck." 130 These strikes included the ranks of workers in the automotive industry in the Midwest, the longshoremen on the coasts, and workers in the cotton and textile industries in New England and the South. ${ }^{131}$

When the Senate reconvened in 1935, a summer of protest was behind

124. Robert F. Wagner, Company Unions: A Vast Industrial Issue, N.Y. TIMES, Mar. 11, 1934, §

9, at 1 (reprinted in 78 CONG. REC. 4229 (1934)).

125. Id.

126. Id.

127. S. REP. NO. $79-1184$, at 4 (1934)

128. Id.

129. Irving Bernstein, The New Deal Collective Bargaining Policy 342-44 (1950).

130. IRVING BERNSTEIN, THE TURBULENT YEARS: A HISTORY OF THE AMERICAN WORKER, 1933$1941315(1969)$

131. Id. 
them. Wagner took the floor and began, sharpening the points from last year with an increased emphasis on liberty, that the legislation was aimed to "make men free in the economic and the political field" by allowing them to organize and self-govern in unions not simply as a matter of extension but rather, continuing the constitutional narrative, to ensure "the preservation of long-recognized fundamental rights." 132 Of course, labor organizing what was not a long-recognized fundamental right, but Wagner's point drew strength from his claim about the meaning of self-government as our ethic more so than tradition.

Between the Senate's deliberations and vote to pass the bill and the start of the House's, momentum was proceeding for passage, when, on May 27, in Schechter Poultry Corp. v. U.S., the Supreme Court struck down Title I of the Recovery Act, which had provided, at least in theory, union association rights. ${ }^{133}$ But the Court's decision only produced momentum in Congress to pass the NLRA, and it motivated FDR to support it. Moreover, Wagner and his colleagues in Congress believed that the NLRA did not suffer from the same constitutional issues as the Recovery Act since the NLRA involved labor issues with more of a direct effect on interstate commerce. ${ }^{134}$

As deliberations proceeded in the House, Congressman Withrow argued, "The right of self-government through fairly chosen representatives is a right which is inherent to the American people and to our American form of government. The bill does no more than guarantee that right to labor." 135 This is a clear instance of ethical constitutional argument: self-government is the American ethic, and we ought to conceive of self-government as having application beyond the nominally political sphere. Congressman Mead argued that the bill would give "to our industrial workers the same general idea of freedom that the founding fathers conferred upon citizens of the United States."136 Freedom was therefore located in worker selfgovernment, a form of self-government based on and guaranteed by our nation's constitutional commitments.

Debate continued and congressmen continued to link union association to freedom. On July 5, 1935, FDR signed the NLRA into law and gave pens to Wagner and William Green. The Act "encouraged" collective bargaining, protecting worker "freedom of association" against employer coercion aimed at thwarting collective bargaining, and set up the institutional administrative mechanisms to enforce the Act, giving newer and clearer powers to the National Labor Relations Board.

132. 79 CONG. REC. 7565 (statement of Sen. Wagner).

133. 295 U.S. 495 (1935).

134. See BERNSTEIN, supra note 130 , at 342-344.

135. 79 CONG. REC. 9691 (statement of Rep. Withrow) (1935).

136. 79 CONG. REC. 9710 (statement of Rep. Mead) (1935). 


\section{FDR}

As he campaigned for the reelection in 1936, FDR defended the passage of the NLRA, and spoke of freedom in economic life as a necessary corollary to political freedom. ${ }^{137}$ FDR's acceptance speech for the Democratic nomination took place in Philadelphia. Over 100,000 people gathered to hear a speech that Senator Wagner and Donald Richberg, another labor law architect, had helped to draft. In the speech, FDR argued that "political freedom" must also extend to prohibit "economic slavery," that the "right to work" was no less central to citizenship than "the right to vote," and that the very "liberty of democracy" is not safe otherwise. ${ }^{138}$ FDR thus drew from the cornerstone commitments of the constitutional order and argued for the necessity of their expression in economic life.

Mimicking the moves of the labor movement and Congress, and in some ways synthesizing them, FDR argued that constitutional self-government extends beyond the political realm: "For too many of us the political equality we once had won was meaningless in the face of economic inequality .... For too many of us life was no longer free; liberty no longer real; men could no longer follow the pursuit of happiness."139 FDR then argued that political liberty required that we recognize other liberties. He spoke to the constitutional consequences of putting "economic and financial control in the hands of the few," which would result in "the destruction of the base of our form of government" and "an autocratic form of government." $140 \mathrm{He}$ proclaimed, "Today we stand committed to the proposition that freedom is no half-and-half affair. If the average citizen is guaranteed equal opportunity in the polling place, he must have equal opportunity in the marketplace." 141 He was arguing, as scholars put it, that "[s]ocial and economic citizenship were simply inseparable from political citizenship." 142 They were entwined in a constitutional order that was economic as well as political.

As he campaigned in the months ahead, FDR pitted industrial control

137. Members of FDR's Administration, of course, also made the same argument and their support of this view was evident as early as 1933. For example, at a meeting of the 1933 Convention of the American Federation of Labor, General Hugh Johnson, the Administrator of the Recovery Administration, which now at least theoretically guaranteed workers the right to bargain collectively, took up the point. He began by discussing Jefferson's limited idea of self-government, then, charting a familiar path, spoke of the complexity and interdependence of society, remarking that, given this, "selfgovernment today" could not exist only in things political but also needed to be achieved in part "through groups in labor." General Hugh S. Johnson, The New Order, AM. FEDERATIONIST, November 1933, at 1181 .

138. Franklin D. Roosevelt, Acceptance of the Renomination for the Presidency (June 27, 1936), in 5 The Public Papers and Addresses of Frankl.in D. RoOSEVElt 230 (1938).

139. Id.

140. Id.

141. Id.

142. See, e.g., Fishkin \& Forbath, supra note 9, at 691. 
against economic self-government through worker association. On Labor Day, he spoke of how before the "hours men and women worked, the wages they received, the conditions of their labor-these had passed beyond the control of the people and were imposed by this new industrial dictatorship." $143 \mathrm{He}$ then connected the labor movement and union association to an economic liberty based in political liberty: "The Fourth of July commemorates our political freedom-a freedom which without economic freedom is meaningless indeed. Labor Day symbolizes our determination to achieve an economic freedom for the average man which will give his political freedom reality."144 The labor movement and the country, he continued, were "building an economic democracy."

\section{The Court}

In the national struggle of the New Deal era, the Supreme Court not only undermined Lochner but also came to see worker association as a fundamental exercise of liberty. To be sure, the Court did not consider whether this liberty was one protected by the Fifth and Fourteenth Amendments' Due Process Clauses. For good reason, however: substantive due process doctrine applies only to governmental, not private, deprivations of liberty. As the labor movement, Congress, and FDR understood it, because the NLRA enacted the right of workers to bargain collectively, the national government was facilitating worker freedom of association, protecting rather than burdening a liberty right. The question was whether the Court would agree.

The Court would. Consider the Court's transition. In Lochner the "right to contract" without state intervention was "part of the liberty of the individual protected by the Fourteenth Amendment." 146 In West Coast Hotel, where the Court again considered the constitutionality of a state minimum wage law, there was a shift. "What is freedom?" the Court asked, continuing that the "Constitution does not speak of freedom of contract." 147 The Court recognized how economic ordering had changed: "Liberty in each of its phases has its history and connotation." 148 The Court then explored the phase of history at hand. Focusing on the unequal distribution of power between employers and employees, as well as their conflicting interests, the Court stated that:

[Employers] naturally desire to obtain as much labor as possible from

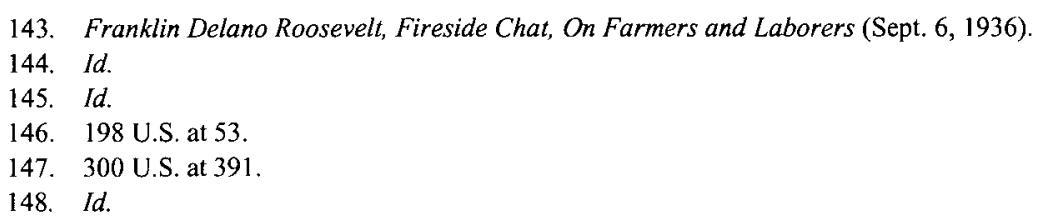


their employ[ee]s, while the latter are often induced by the fear of discharge to conform to regulations which their judgment, fairly exercised, would pronounce to be detrimental to their health or strength. In other words, the proprietors lay down the rules and the laborers are practically constrained to obey them. In such cases, selfinterest is often an unsafe guide, and the legislature may properly interpose its authority. ${ }^{149}$

Note the transformation. Liberty was no longer located in the exchange, because the exchange became an unbalanced form of "self-interest." The Court continued that "recent economic experience" had shown not only workers' "unequal position with respect to bargaining" but also the deleterious effects of this, because "denial of a living wage is not only detrimental to their health and well being, but casts a direct burden for their support on the community." 150 Rather than speaking abstractly about contract, the Court focused on the parties, their social lives, and the extent to which contracting could reflect their actual freedom. The Court concluded that the contract was often not one of parity and, therefore, that setting a minimum wage did not impinge upon the liberty protected by substantive due process doctrine. Indeed, in light of the health and security concerns of citizens, it concluded that the regulation was well within the state's power. ${ }^{151}$

A couple of weeks later, the Court handed down its opinion in NLRB v. Jones \& Laughlin Steel Company. ${ }^{152}$ There, the Court considered the constitutionality of Section I of the NLRA, particularly whether Congress could regulate labor-management disputes under the Commerce Clause. The Court concluded that it could, because the statute reached and regulated labor disputes such as strikes that would have an "obvious" and "potentially catastrophic" effect on interstate commerce. ${ }^{153}$ Along the way, worker organization became for the Court a "fundamental right" and one which the Court touted for its features of "free exercise," "self-representation," and "freedom of choice."154 Workers had a right to select "representatives of their own choosing"155 and to "self-organization and freedom." 156 Thus, the Court was making a closing statement about economic freedom: economic

149. Id. at 394 .

150. Id. at 399 .

151. Id.

152. 301 U.S. 1 (1937).

153. Id. at 40; see also id. at 37 ("Although activities may be intrastate in character when separately considered, if they have such a close and substantial relation to interstate commerce that their control is essential or appropriate to protect that commerce from burdens and obstructions, Congress cannot be denied the power to exercise that control.").

154. Id. at 33 .

155. Id.

156. Id. at 43 
freedom was embodied in the labor union and was lawfully protected by the NLRA.

The Court's analysis had several remarkable features. First, following the language employed by Wagner and other congressmen in legislative deliberations, the Court conceived of labor organization as a "fundamental right." This was no hollow claim: it was a constitutional claim. Second, when describing why the right both exists and reaches fundamental status, the Court analogized labor association to political association, focusing on representation and exercise. One could pluck out the Court's various sentences and think it was speaking about First Amendment freedom of association of citizens attempting to associate to elect political representatives rather than worker association. This, I take it, is the point. The opinion therefore harmonizes with the theory put forward by labor, congressional leaders, and FDR: it links the right of labor organization to the exercise of freedom and self-governing qualities in the economic sphere. With this decision, it was no longer necessary to "masquerade" 157 a labor law as a health or safety law. Labor organization was now a form of selforganization and an exercise of freedom.

NLRB $v$. Jones \& Laughlin is, in this regard, an important decision in the struggle to define economic liberty. While West Coast Hotel Co. is recognized for undermining the premises of Lochnerism, the extent to which the Court went to make an affirmative statement about how economic liberty is really expressed in $N L R B \mathcal{V}$. Jones \& Laughlin matters; it closes the circle. And although $N L R B v$. Jones \& Laughlin is not a substantive due process case, the Court does identify labor organizing as a "fundamental right" of "freedom and self-organization." This suggests that a substantive due process claim could be made upon a state deprivation. As Justice Brandeis stated in Whitney v. California, substantive due process doctrine protects "all fundamental rights comprised within the term liberty."158 The delineation of worker self-organization as one such "fundamental right" of "freedom" sets up the logical premises for the application of substantive due process in the face of a governmental deprivation of collective bargaining rights. ${ }^{159}$

157. Nourse, supra note 41 , at 768.

158. Whitney v. California, 247 U.S. 357, 373 (1927). This proposition was cited with authority in Casey as the Court described substantive due process. See Casey, 505 U.S. at 847.

159. And while one might ask whether burdening workers' association rights is a significant enough infringement of an important freedom to justify such a decision, it is not clear that union organization is any less important than, say, having one's child learn a particular language or choosing a particular school. See Meyer v. Nebraska, 262 U.S. 390 (1923); Pierce v. Society of Sisters, 268 U.S. 510 (1925). Its importance, indeed, made labor struggles the "dominant focus of public life" during the era. FONER, supra note 55 , at 118 . One might also question whether impeding the State from burdening union association is problematic because doing so shifts the balance between employers and employees. But substantive due process cases, in prohibiting the State from burdening freedom, always bear upon institutional structures, including the State's ability to control schools, regulate prisons, regulate 
It is also worth noting that when the Supreme Court protected worker association rights under the First Amendment less than a decade later, it at times seemed to engage in substantive due process-like reasoning. In 1945, the Supreme Court held in Thomas v. Collins that the "rights of assembly and discussion" of a union are protected by the First Amendment. ${ }^{160}$ In so finding, the Court stated that its task was to discern "where the individual's freedom ends and the State's power begins." 161 This is nearly exactly the formulation of Justice Harlan's dissent in Poe $v$. Ullman - the precursor case to Griswold-where he set up modern substantive due process doctrine, focusing on how the doctrine parses the balance between "the liberty of the individual" and the "demands of organized society." 162

The similarity in reasoning makes sense: The First Amendment has been offered as an additional textual justification for substantive due process doctrine, ${ }^{163}$ and Fourteenth Amendment substantive due process doctrine protects forms of activity and association that often find refuge as well in the First. ${ }^{164}$ At the same time, when the Court protected the association right, it did so under a traditional First Amendment framework, and it was making a different move than that made by the New Deal architects. It was not analogizing worker association to political association; it was asking whether worker association directly bore on political discussion. ${ }^{165}$

domestic affairs, and so on. See Turner v. Safley, 482 U.S. 78 (1978); Griswold, 381 U.S. at 484-86; Pierce, 262 U.S. 390; Meyer, 198 U.S. 45 (1905). And a constitutional decision, like the one ultimately protecting worker association rights under the First Amendment discussed below, would not necessarily require employers to bargain with unions; that requirement would be statutorily, rather than constitutionally, imposed. Thomas v. Collins, 323 U.S. 516, 534 (1945).

160. 323 U.S. 516,534 (1945).

161. 323 U.S. at 528 .

162. 367 U.S. at 539 (stating that substantive due process "represent[s] the balance which our Nation, built upon postulates of respect for the liberty of the individual, has struck between that liberty and the demands of organized society").

163. See Tribe, supra note 21 , at 1939.

164. Consider, for example, the sources that indicate that intimate association is protected by not only the Fourteenth but also the First Amendment. See, e.g., Starling v. Bd. of Cnty. Comm'rs, 602 F.3d 1257, 1260 ( 1 l th Cir. 2010) (describing the "First Amendment right to intimate association"); Kenneth L. Karst, The Freedom of Intimate Association, 89 YALE L.J. 624, 655 (1980).

165. The Court thus concluded that "[f]ree discussion concerning the conditions in industry and the cause of labor disputes" is "indispensable to the effective and intelligent use of the processes of popular government to shape the destiny of modern industrial society." 323 U.S. at 523 . The Court continued that to draw a line between economic and political association would be "at once too simple, too general, and too inaccurate to be determinative." Id. at 531. But this was so because of the link to political selfdetermination: "Labor is free to turn its publicity on any labor oppression, substandard wages, employer unfairness, or objectionable working conditions." Id. at 547.Labor disputes therefore related also to the "public need for information and education with respect to the significant issues of the times." Thornhill v. Alabama, 310 U.S. 88 (1940); see also id. at 102-03 ("In the circumstances of our times the dissemination of information concerning the facts of a labor dispute must be regarded as within that area of free discussion that is guaranteed by the Constitution. It is recognized now that satisfactory hours and wages and working conditions in industry and a bargaining position which makes these possible have an importance which is not less than the interests of those in the business or industry directly concerned. The health of the present generation and of those as yet unborn may depend on these matters, and the practices in a single factory may have economic repercussions upon a whole region and affect widespread systems of marketing. The merest glance at State and Federal legislation on the subject 
That said, the Court also gestured towards a more capacious protection of freedom of worker association, which was, as Aviam Soifer put it, "not limited to political or religious matters" and indeed "broad enough to include private as well as public gatherings, economic as well as political subjects."166 That conception would narrow over the years, as the Court would come to focus its freedom of association jurisprudence on intimate and expressive association, linking the latter to its role in the political process. ${ }^{167}$ Intimate association would become the refuge for "nonpolitical" association, and it would, perhaps surprisingly, draw the Court right back into the heart of substantive due process jurisprudence.

\section{E. Synthesis: Association and Liberty}

As the sections above show, the history of the repudiation of Lochnerism is also the history of the federal government accepting an alternative vision of economic freedom rooted in worker association and decision-making. In this section, I consider the how that alternative vision transformed the American concept of economic liberty at the center of the constitutional political economy.

By likening relations between workers in the economic sphere to the relations between citizens in the polity-putting forward both associations as ones where freedom is exercised - the architects of the New Deal made an important move. They challenged the then-prevailing notion that politics was a complex organizational sphere where collective decision-making occurred and where freedom was therefore exercised by participating in self-government and that other domains would somehow order themselves to be conducive to freedom if we could only, say, spread property broadly. ${ }^{168}$ The mistake of Lochnerism, as Owen Fiss explores in his volume on the Court during the era, was to assume that the conditions of ordering within social and economic spheres would reflect liberty only if the state left them alone by, for example, not regulating employment contracts. ${ }^{169}$ This Article has thus far shown how the New Deal architects instead showed that the transition to a system of wage-earning had made economic life a complex organizational sphere where governance

demonstrates the force of the argument that labor relations are not matters of mere local or private concern.") (internal citations omitted).

166. Aviam Soifer, Freedom of Association: Indian Tribes, Workers, and Communal Ghosts, 48 MARYLAND L. REV. 350, 363 (1989). At the same time, the Court connected labor association to political discussion. The Court concluded that "[f]ree discussion concerning the conditions in industry and the cause of labor disputes" is "indispensable to the effective and intelligent use of the processes of popular government to shape the destiny of modern industrial society." 323 U.S. at 523; see also Thornhill, 310 U.S. at 102-103.

167. See generally id.; see also Roberts v. U.S. Jaycees, 468 U.S. 609 (1984).

168. See FISS, supra note 36 , at 157-59, 389-90.

169. See id. 
arrangements bore on the existence or absence of freedom. In this way, these New Deal architects chipped at the wall of negative liberty and its assumption of state non-interference, and provided growing recognition of the social conditions of freedom.

The New Deal therefore offered a practical philosophy that did not so much challenge the model of economic ordering based on the agrarian entrepreneur who in the absence of restraint enjoyed liberty to farm from his property and create his own enterprise, as much as it undermined its ability to meaningfully bear upon the world that citizens inhabited. The citizen, we learned, must work, which becomes its own complex endeavor. The states' agnosticism toward the economic ordering of work could mean, for the citizen, seven days' work per week or five, eighty hours' work or forty, being hired in the mill village with his or her children or sending the children to school, having a wage that allows him or her to afford a life outside work or not, and so on. A citizen's best chance at avoiding domination in this complex social sphere comes through an act that takes its image from the political: joining with co-workers in association, forming together a will, and using their power to bargain for basic forms of security, the kind of security that underlies individual freedom and republican citizenship. The model conducive to economic freedom becomes the factory rather than the farm, and association rather than isolation.

The New Deal therefore worked against a purely negative conception of liberty in an economic sphere that was before-conceived as a purely private sphere. To fill the blank, yawning space that had defined negative freedom in private life, the architects of the New Deal turned to the features of association that defined political freedom. They broke down the features and attributes of self-government and grafted political notions of association, exercise, and collective decision-making onto a private sphere of ordering, showing how these could be indicia of the social conditions of freedom within the sphere and how they were reflected in labor association.

The New Deal transformation thus etched into our constitutional architecture the idea that forming a collective will could become an exercise of freedom with resonance beyond the political domain. Economic life, the architects of the New Deal knew, looked more like political life than the proponents of Lochnerism presumed. Economic life was a domain of struggle, solidarity, resource distribution, and mutual interdependence. In such a domain, collective solutions were palatable. Since the sum and substance of political liberty was that the people formed in association to make important decisions together in mutual regard, the New Dealers drew from this an account of worker freedom in association.

Thus, while Americans had offered a rich, associative, and exercise-based conception of political liberty, that notion had been accompanied by a simplistic view of social and economic life, so serenely ordered to produce 
liberty without effort or coordination, a notion which could not keep up with the manner in which industrialism introduced forms of governance and interdependence into the economic sphere. As the basis for a thick and active notion of political liberty and a thin and negative notion of private liberty began to dissipate with the Industrial Revolution, labor could not rest its hopes on the right to be let alone: it formed its image of liberty in the image of the state's freedom, and eventually turned to the state for recognition. Its claim resonated not in the absence of restraint but instead in the immanent value of association, exercise, and mutual will-formation. Labor's freedom took its shape and form, and its value, from constitutional freedom. There was no theory of labor's freedom without first making reference to the state's freedom.

By analogizing from political liberty exercised in association towards an account of economic liberty, the architects of the New Deal order did something larger, something perhaps even they could not predict. By being sensitive to the relationships within the economic sphere ${ }^{170}$ and transporting the attributes of self-governing association onto association within it, they provided a clue as to what liberty might mean in previously-identified "private" spheres more generally. Suddenly, the economic world looked different. Perhaps it was only a matter of time before other social domains would follow course.

\section{Post-GRISWold SubStantive DUE PRocess}

Substantive due process was not laid to rest with Lochnerism. As the Supreme Court exhumed the doctrine in Griswold, it made it clear that its endeavor was miles - and decades-removed from Lochnerism. At the same time, the Court developed a strand within the doctrine protecting intimate association. But the Court's efforts to fashion a doctrine tailormade for intimate life and distanced from the economic struggles over liberty in the first half of the twentieth century led it to miss just how connected its endeavor to define intimate liberty was to the New Deal endeavor to define economic liberty. The architects of the New Deal and the architects of modern substantive due process both in part define freedom around "non-political" association, and in this way are importantly linked. In the latter case, however, the model is the marital union rather than the labor union. Thus, the association would not be economic in the modern sense, but instead would return to the roots from which the word "economy" was defined-the home-and define intimate freedom within that

170. Bruce Ackerman focuses on how the New Deal offered a sphere by sphere approach, which animates both the civil rights revolution and modern substantive due process cases. 3 BRUCE ACKerman, We THE PEOPLE: CIVIL Rights ReVolution ch. 13 (2013). His account, however, does not focus on how the attributes of political self-government structure and guide the spherical analysis. 
domain. $^{171}$

\section{A. The Ghost of Lochnerism}

The Supreme Court again turned to employing substantive due process as, on the heels of the women's liberation movement and the gradual transformation of American family life, movements brought questions about women's reproductive autonomy and citizens' personal and sexual rights to the Court to respond to what they conceived of as governmental deprivations of liberty. ${ }^{172}$

As the doctrine again became central to a battle to define liberty, its detractors were quick to note its problematic earlier association with Lochnerism. And, even those who think the doctrine has continuing vitality have noted its shaky foundations in the first half of the twentieth century. Under this account, Meyer v. Nebraska ${ }^{173}$ and Pierce v. Society of Sisters ${ }^{174}$ — cases about the liberty of parents to raise their children and make educational decisions for them-are regarded the "two sturdiest pillars of the substantive due process era" and the "survivors of the largely discredited Lochner era." 175 And so, the narrative goes, Lochnerism collapsed, leaving only these two cases in the early 20th century canon, and substantive due process was dormant until 1965, when it was "reborn in the guise of Griswold v. Connecticut." 176 It then marched its path from Griswold177 to Obergefell $v$ Hodges. ${ }^{178}$

Judges and scholars who criticize the doctrine rely on this narrative about the shaky foundations of the doctrine and those who employ it must explain how the case before them differs from the string of cases preceding West Coast Hotel Co. ${ }^{179}$ However, the Court's hurry to cast off the history of the

171. See, e.g., Jonathan Baert Wiener, Global Environmental Regulation: Instrument Choice in Legal Context, 108 YALE L. J. 677, 799 (1999) (noting that economics is "derived from the ancient Greek word 'oikos,' meaning 'house"').

172. See David J. Garrow, Liberty AND SeXuality (1998); Mary L. Dudziak, Just Say No: Birth Control in the Connecticut Supreme Court Before Griswold v. Connecticut, 75 IOWA L. REV. 915 (1990); Eskridge, supra note 28, at 2236-40; see also Ryan L. Williams, The Paths to Griswold, 89 NOTRE DAME L. REV. 2155 (2014) (emphasizing the doctrinal and jurisprudential debates and shifts that led to Griswold).

173. 262 U.S. 390 (1923) (overturning a Nebraska law prohibiting the teaching of foreign languages to children on the grounds that the law interfered with the liberty of the parents to raise their children).

174. 268 U.S. 510 (1925) (striking down an Oregon law that mandated that students attend public schools on the ground that it interfered with the liberty of parents to raise their children).

175. Tribe, supra note 21 , at 1934.

176. Id. In a precursor to Griswold, Justice Harlan foreshadowed its substantive due process reasoning. Poe v. Ullman, 367 U.S. 497, 539 (Harlan, J., dissenting).

177. 381 U.S. $479,484-86$ (1965).

178. 567 U.S. - (2015).

179. See, e.g., United States v. Windsor, 570 U.S. __, slip. op. at 17 (2013) (Scalia, J., dissenting) (noting that the majority never utters the "dread words "substantive due process"' and noting its state of disrepair); Casey, 505 U.S. at 864 (explaining how the premises underlying Lochner had been proven to be untrue and therefore why West Coast Hotel Co. was decided the way it was and why the doctrine 
constitutional struggle surrounding economic freedom makes it throw away valuable resources and miss important connections. The New Deal embrace of a liberty right to economic association is linked to the Court's eventual embrace of a right to intimate association.

\section{B. Griswold and Intimate Association}

Griswold brought the Court into a battle over contraception and family planning. Two features about the Court's decision are relevant. The first is its understanding of Lochnerism and its repudiation, and the second is how the Court continues, though in fits and starts, the New Deal mode of constitutional reasoning that rejected Lochnerism, placing the Court on a path towards recognizing a liberty-based right to intimate association.

The statute at issue in Griswold prohibited the use of "any drug, medicinal article or instrument for the purpose of preventing conception." 180 The law had been challenged before in Poe v. Ullman, but the Supreme Court dismissed the appeal, concluding that since there was no threat of prosecution, or prosecution itself, there was no case or controversy. ${ }^{181}$ Justice Harlan dissented, urging the Court to take the case and expounding the meaning of the doctrine. He wrote that:

[T] he full scope of the liberty guaranteed by the Due Process Clause cannot be found in or limited by the precise terms of the specific guarantees elsewhere provided in the Constitution. This 'liberty' is not a series of isolated points pricked out [but is a] rational continuum which, broadly speaking, includes a freedom from all substantial arbitrary impositions and purposeless restraints. ${ }^{182}$

Justice Harlan thus framed substantive due process as being about negative liberty, the "liberty of the individual," and the balance "struck between that liberty and the demands of organized society." 183

The issue came to the Court again after a birth control clinic was opened and an arrest made. The Court, in a deeply divided opinion, ${ }^{184}$ concluded that the married couple challenging the statute had standing and that the statute unconstitutionally infringed on the "zone of privacy created by several fundamental constitutional guarantees," 185 among them the Due Process Clause and the First Amendment "right of 'association,' [which is] more than the right to attend a meeting [and] includes the right to express

\footnotetext{
has continuing vitality).

180. 381 U.S. at 480.

181. 367 U.S. at $516-22$.

182. 367 U.S. at 543 (Harlan, J., dissenting)

183. Id. at 542 .

184. There were three concurrences (Justices Goldberg, Harlan, and White) and two dissents (Justices Black and Stewart). See id. at 487-530.

185. Id. at 485 .
} 
one's attitudes or philosophies by membership in a group or by affiliation." 186

As the Court employed substantive due process doctrine anew, it struggled awkwardly with the doctrine's history. The Court rejected the notion that Lochner "should be [their] guide," deciding that they did not sit as a "super-legislature to determine the wisdom, need, and propriety of laws that touch economic problems, business affairs, or social conditions." 187 The Court thus appeared to move away from any consideration of the economic sphere and the constitutional struggles that took place within it during the early to mid-twentieth century, turning to the seemingly safer personal and intimate sphere by stating that unlike laws that "touch" economic problems or social conditions, the Connecticut law "operate[d] directly on an intimate relation of husband and wife."188 Like Meyer and Pierce, Griswold was seemingly an acceptable use of the doctrine because it dealt with a personal realm, rather than the economic realm.

The Court, however, was misguided in its reading of history. Lochner was not concerned with determining the "wisdom, need, and propriety" of laws that touch economic problems; it was concerned, rightly so, with protecting liberty in the workplace in the face of an alleged governmental deprivation. The issue was how it defined liberty initially - but, if we take $N L R B v$. Jones \& Laughlin seriously, only initially. More importantly, by turning its gaze away from the struggles to define freedom in the economic sphere, the Court turns away from a constitutional struggle that, when fully understood, involves the protection of "non-political" forms of association - the very protection the Court itself would engage in as it established a liberty-based right to intimate association over the next few decades. The Court could have benefitted from a stronger understanding of the history of the era.

Begin with the Court's first move. Just as New Dealers drew from the image of political association as an exercise of freedom and analogized it to economic association, Griswold analogized political association to intimate association. The Court cited First Amendment case law on the "association of people" and spoke to the "protection of forms of 'association' that are not political in the customary sense, but pertain to the social, legal, and economic benefit of their members." 189 Scholars rightly critique this move by noting that the Court cites cases about the freedom of political association that, historically, had nothing to do with intimate association. ${ }^{190}$

186. Id. at 483 .

187. Id. at 482 .

188. Id.

189. Id.

190. AKHIL REED AMAR, AMERICA'S UnWritTEN CONSTITUTION: THE PRECEdents AND PRINCIPLES WE LIVE BY $117-118$ (2012) ("The core Founding-era right of 'the people' to 'assemble' centers on citizens' entitlement to gather in public conventions and other political meeting grounds."). 
Scholars comment that the freedom of association referenced in those cases draws from a Founding notion of the people associating in the political sphere and is "miles removed from the erotic urges of a man and woman seeking to 'assemble' on a bed." 191

However, once one takes the New Deal's move of focusing on associative exercises of liberty beyond the political sphere, where important choicemaking and mutual self-direction occurs, and analogizing those associations to political association at the core of constitutional liberty, the move in Griswold is not so novel. Counterpoised against the traditionally negative and individualistic conceptions of private liberty in American life, the New Deal provides a foundation for liberty rights-reasoning in the context of the marital relationship: likening mutual self-determination and choice-making to political association, and from the attributes of political association, deriving an exercise account of freedom in the personal sphere. The Court, that is, was being analogical in a New Deal fashion.

While the Court both relied on a notion of associational freedom, and drew support, like New Dealers, from political concepts of association, its analytical framework for discussing intimate association as a liberty-based right was somewhat weak. This may be explained by the fact that Justice Douglas, who was assigned the opinion, initially wrote a stronger opinion focusing on freedom of association and intimacy, strengthening the analogy between political association and intimate association, but Justice Brennan urged him to pivot more towards privacy. ${ }^{192}$ Had Justice Douglas not been convinced by Justice Brennan, the connection between the New Deal theory of association and Griswold may have been stronger.

Instead, the Court oddly mixed liberty and privacy without strong doctrinal or theoretical clarification of either concept. As the Court outlined the forms of intimate and personal association between husband and wife at stake, it did not flesh out in rich detail how marriage was an association where persons exercise freedom, honing in on the choices that couples make together which define their freedom. The Court turned instead to how the intimate associations linked to "zones of privacy." 193 Its examples turned to the home, and the "penumbral rights of "privacy and repose."'194 Marriage, then, became "a right of privacy older than the Bill of Rights." 195 The Court thus appeared to return to negative liberty, but only momentarily. It continued that marriage was "a coming together for better or for worse,

191. Id.

192. See John D. Inazu, The Unsettling “Well-Settled" Law of Freedom of Association, 43 CONN. L. REV. 149, 159 (2010) (overviewing the exchange between Justices Douglas and Brennan); see also BERNARD SCHWARTZ, THE UNPUBLISHED OPINIONS OF THE WARREN COURT 237 (1985).

193. Id. at 484

194. Id at 485 (citations omitted).

195. Id. at 486 (emphasis added). 
hopefully enduring, and intimate to the degree of being sacred" and "an association that promotes a way of life, not causes; a harmony in living, not political faiths; a bilateral loyalty, not commercial or social projects." 196

In one way, the latter part of this passage positions Griswold as the inheritor and continuer of the logic of the New Deal transformation. The Court is engaging in a sphere-sensitive inquiry, focusing on how the association "promotes" a particular way of life that is unique to the sphere and produces a "harmony in living." The case is thus not merely about the right to be let alone on the assumption that the intimate order will naturally produce the conditions of liberty. It focuses on the marital union as an exercise in a particular type of living and association that embodied liberty, and draws from First Amendment political association to structure its analysis about liberty within intimate association.

Reasoning from Griswold, Laurence Tribe thus writes that "it was the supposed sanctity of another and more personal version of self-government, that of the marriage contract, that gave the Court its rhetorical and philosophical entree." 197 It is possible to read the opinion as Tribe does, and doing so would strengthen the link between the New Deal protection of associational freedom and Griswold. But the problem is that the Court does not provide much basis for the conclusion that marriage is a personal version of self-government. When the Court speaks of marriage as an important form of association, it heads in the direction of defining a sphere of mutual self-direction, especially when it notes that such an association "promotes a way of life." Nevertheless, all of that language is framed in a sentence that begins with marriage as a "right of privacy." Privacy is thus not linked merely to reproduction; it is linked to the Court's definition of martial association as liberty-based.

One need not think long to understand the various ways in which marriage is a public and communal institution as much as a private one. ${ }^{198}$ As Kenneth Karst said, "We pay a price for this judicial evasion. Calling the right[] in Griswold ... [one] of privacy invites the rejection of comparable claims on the ground that, after all, they do not rest on any concerns about control over the disclosure of information." 199 That is, not all exercises of liberty within the scope of intimate association are private ones-think of the public and communal aspects related to entering into and continuing marriage-but this does not mean that they are not deserving of constitutional solicitude.

At the same time, the pivot towards privacy in Griswold may have

196. Id.

197. Tribe, Fundamental Right, supra note 21, at 1939.

198. See, e.g., Allison Anna Tait, Polygamy, Publicity, and Locality: The Place of the Public in Marriage, 2011 MiCH. ST. L. REv. 171 (2011).

199. Karst, supra note 164 , at 664. 
reflected the state of marital relationships at the time. The marital household was in flux as the efforts for gender equality upended notions of household arrangement, career planning, gender roles, and more. ${ }^{200}$ The efforts for gender equality during the era were precipitated in part on viewing marital association through the lens of self-government: on ensuring that the private domain would shift from "a hierarchical relationship, premised on gender complementarity, to one of mutual self-government, premised on gender equality."201 Viewing martial association through the lens of selfgovernment connects it to the New Deal. Of course, one can doubt that the model of self-government is as apt an analogy for the married couple as it is for the labor union, ${ }^{202}$ and still agree that the transformation of marriage through the prism of gender equality makes an account of associative freedom stronger. ${ }^{203}$ Transforming marriage to provide increased forms of equal respect and willful choice-making is important to establishing a stronger account of associational liberty. ${ }^{204}$

Even considering the state of flux, one can wonder whether the Court, in light of its views about then-existing "bilateral choice" and "harmony" in

200. See, e.g., SUSAN BROWNMILLER, IN OUR TIME: A MEMOIR OF REVOLUTION 102-35 (1999); FLORA DAVIS, MOVING THE MOUNTAIN: THE WOMEN'S MOVEMENT IN AMERICA SINCE 1960 (1991); KRISTIN LUKER, ABORTION AND THE POLITICS OF MOTHERHOOD 92-125 (1984); LINDA C. MCCLAIN, The Place of FAmILIES, Fostering CAPACITY, EQuality, AND RESPONSIBILITY chs. 2 \& 3 (2006); see generally LAURI UMANKSY, MOTHERHOOD RECONCEIVED: FEMINISM AND THE LEGACIES OF THE SIXTIES (1996).

201. See MCCLAIN, supra note 200, at 60-61; see also Tribe, supra note 21 , at 1899 (describing his project as "relating the approach the Court took in Lawrence to the overarching concepts of individual and collective self-government-that is, to the ways in which the commitments we make to our principles and to one another, in the context of associations ranging from the most intimate to those with the polity as a whole, constitute the essential core of constitutionalism and the cornerstone of American liberty") (emphasis added); id. at 1939 (describing the marriage contract as "another and more personal version of self-government").

202. Unlike labor unions, married couples need not follow regularized, majoritarian decisionmaking processes, and one would suspect that most do not, happily settling for more informal processes. There are many ways to organize a marital relationship, and some veer rather far from the image in mind.

203. While my endeavor in this Part is to connect the affirmation of association in post-Griswold jurisprudence to the New Deal affirmation of association, it is not to argue normatively about whether marriage generally reflects or promotes freedom.

204. The ongoing struggle to transform marriage as an institution reflecting gender equality can be viewed through the lens of the New Deal reordering of private spheres. First, the transformation has New Deal linkages insofar as citizens came to recognize that the marital relationship, like the workplace, was not perfectly ordered to enable liberty if the state left it be; it was a social domain, full possibilities for both domination and freedom, flourishing and floundering, among other things. The untangling of the mystical image of coverture-with husband and wife transforming into a juridical entity through which the husband spoke for both-reflected a frank confrontation with the social conditions of freedom in marriage. The transformation of wives into juridical actors played important role, beginning at least with trust forms such as the separate estate. See Allison Anna Tait, The Beginning of the End of Coverture: A Reappraisal of the Married Woman's Separate Estate, 26 YALE J. L. \& FEM. 1 (2014) ("Through the configuration of the wife as a separate entity, this jurisprudence created fissures in the brittle surface of coverture and introduced the idea of divided household sovereignty."). The end of coverture and the shift towards gender equality share with the demise of Lochnerism the insight that power imbalances exist in private spheres, and that an account of negative liberty will leave the state unresponsive to those imbalances and their broader effects. 
martial arrangement, could have provided a stronger model of marriage as an intimate association expressing liberty at the time. The Court could have focused more on marriage as a form of association where persons can be engaged in a mutual and willful project of making important decisions together-"shaping, expressing, or imparting values" for themselves or others, and through those efforts, "choos[ing] the contours, sexual and otherwise, of their personal association." ${ }^{205}$ Choice is critically important to an account of liberty inhering in intimate association, and divorce-which itself was becoming more common at the time of Griswold-plays a role in legitimating intimate association. As Kenneth Karst put it in an article on intimate association, "[i]t is the choice to form and maintain an intimate association that permits full realization of the associational values we cherish most." ${ }^{206}$ Stressing the point of choice-making, Karst continues:

To say in a given case that the sovereign must keep its hands off an individual's associational choice is merely to reaffirm that moral responsibility lives in the only place it can live, the individual conscience. It is meaningless to speak of morality when there is no choice. The freedom to choose our intimates and to govern our day-today relations with them is more than an opportunity for the pleasures of self-expression; it is the foundation for the one responsibility among all others that most clearly defines our humanity. 207

Reasoning about liberty in the intimate sphere, the Court could thus have focused further on marriage as an associative union where people exercise important and formative decision-making together - and indeed make some of life's most important decisions in mutual regard and consideration. ${ }^{208}$ The Court could have outlined the liberty exercised in the self-governing choices that married couples make - at times together, and at times on their own and in consideration of one another-not only about child-rearing but also about reproduction itself. Those choices speak to how citizens plan and order their lives, make and express commitments to one another, share ideas, and exist as willful and connected persons.

Griswold thus inhabits a transitional space in the post-New Deal constitutional architecture. It builds on the New Deal forms of constitutional reasoning about association, analogizing intimate association to political association and focusing, albeit without much elaboration, on the positive

205. Tribe, supra note 21 , at 1939.

206. Karst, supra note 164, at 637 ("The full value of long-term commitment is also realizable only when there is freedom to remain uncommitted. Not only is the freedom to reject or terminate an intimate association valuable in its own right; it also promotes the realization of values in an intimate association that endures.").

207. Id at 692 .

208. In an era in which marriage is, and has long been in decline, any right to intimate association should move beyond the institutional model. See id. 
aspects of bilateral choice-making in association in their relationship to liberty. ${ }^{209}$ It also turns to the tradition of negative liberty, pivoting to privacy. One is aided in understanding Griswold's steps towards a substantive due process right of intimate association, though, if one understands the New Deal linkage of "non-political" association with liberty and its affront to the reign of negative liberty.

\section{Roe, Casey, and Negative Liberty}

The Court's abortion jurisprudence, on the other hand, summoned the image of individual rights and negative liberty, and therefore was linked to the theory of state non-interference associated with Lochnerism. As I argue here, as others have elsewhere, ${ }^{210}$ these cases are easily distinguished from Lochner. However, in other ways, the cases are also linked to the New Deal repudiation of Lochnerism. These cases exhibit a mixed tradition, where the Court invokes the concepts of negative and positive liberty side-by-side, as old and new concepts intertwined. ${ }^{211}$

Casey, more than Roe, provided a reckoning with liberty. Roe, in which the Court upheld a woman's right to terminate a pregnancy based on a trimester framework, was premised on a "right to privacy, whether founded in the Fourteenth Amendment's concept of personal liberty or in the Ninth Amendment's unenumerated rights." 212 The Court therefore focused on how "there has been recognized right of personal privacy, or a guarantee of certain areas or zones of privacy, [which] does exist under the Constitution." 213 Privacy, the Court reminded, is "implicit in the concept of ordered liberty," 214 but the meaning of liberty-its substance-is far from sight.

Casey, in which the Court affirmed the essential holding of Roe but replaced its trimester framework with an undue burden test, brought the Court back into exploring the meaning of liberty. Casey, though, as the Court stresses, is most directly about individual liberty, rather than associational liberty. ${ }^{215}$ In reasoning about the constitutional protection of liberty, the majority declined to "suppose that the Due Process Clause protects only those practices, defined at the most specific level, that were protected against government interference by other rules of law when the

209. The Court would extend the right to possess contraception to non-marital couples shortly after, although on equal protection grounds. See Eisenstadt v. Baird, 405 U.S. 438 (1972).

210. See, e.g., Tribe, supra note 21.

211. See also Ann Alstott, Neoliberalism in U.S. Family Law: Negative Liberty and Laissez-Faire Markets in the Minimal State, 77 L. \& CONTEMP. PROBS. 25-42 (2015).

212. Roe v. Wade, 410 U.S. 113,153 (1973).

213. Id. at 152 .

214. Id.

215. Casey, 505 U.S. at 848-852 (referring to "personal liberty" and the "liberty of the individual" and the "right of the individual"). 
Fourteenth Amendment was ratified." 216 Instead, the majority spoke of a "realm of personal liberty" which includes the "most basic decisions about family and parenthood." 217 Turning again "to personal decisions," the Court said:

These matters, involving the most intimate and personal choices a person may make in a lifetime, choices central to personal dignity and autonomy, are central to the liberty protected by the Fourteenth Amendment. At the heart of liberty is the right to define one's own concept of existence, of meaning, of the universe, and of the mystery of human life. Beliefs about these matters could not define the attributes of personhood were they formed under compulsion of the State. ${ }^{218}$

In one sense, Roe and Casey continue a tradition of thinking about individual rights in terms of negative liberty: realms the government ought not to enter. This, in turn, made the move towards privacy sensible. As with Griswold, precisely because the cases involved a woman's bodily control and integrity, and the extent to which the government should not interfere with it, did women's privacy come into play. However, the rejection of Lochnerism was not a wholesale rejection of negative liberty. The premises of Lochnerism were undermined because non-interference did not protect liberty; just the opposite. In Roe and Casey, however, there was no social relationship like the employer-employee relationship that might undermine the individual freedom. Governmental non-interference strengthened the woman's freedom. It kept with her the decision about how to control her body, and also much of the future arc of her life plan.

However, the Court in Casey also gestured towards a New Deal-like affirmation of positive liberty, evincing a mixed tradition. The Court's reference to "defin[ing] one's own concept of existence, of meaning, of the universe, and of the mystery of human life," syncs well with Isaiah Berlin's description of positive liberty: "I wish to be the instrument of my own, not of other men's, acts of will. I wish to be a subject, not an object; to be moved by reasons, by conscious purposes, which are my own, not by causes which affect me, as it were, from outside."219 Indeed, Berlin then shifts to the consequences of having the state or "other men" make such choices, ${ }^{220}$ just as the Court shifts to how a woman's complex choice in making such reproductive decisions is "too intimate and personal for the State to insist,

\footnotetext{
216. Id. at 847 .

217. Id.

218. Id. at 851 .

219. Isaiah Berlin, Inaugural Address Before the University of Oxford (Oct. 31, 1958), in ISAIAH BERLIN, TwO CONCEPTS OF LIBERTY, IN LIBERALISM AND ITS CRITICS 118,131 (1969).

220. Id.
} 
without more, upon its own vision of the woman's role."221 This was because, the Court continued, "[t]he destiny of the woman must be shaped to a large extent on her own conception of her spiritual imperatives and her place in society."222 It was therefore "this dimension of personal liberty that Roe sought to protect"223 because liberty is related to the ways-and here the Court drew in the relational elements-that "people have organized intimate relationships and made choices that define their views of themselves and their places in society." 224

Second, as that quote shows, the Court reasoned about sphere linkages and blurred the line between public and private-focusing on how protecting a woman's individual freedom in the personal realm links to how she organizes her life and the kinds of relationships she has both with others and as a citizen in society. That is, as Jane Schacter puts it, "[t]o link the ability of women to choose to terminate a pregnancy with the ability 'to participate equally in the economic and social life of the Nation' is to place reproductive autonomy squarely in the realm of citizenship and social participation." ${ }^{225}$ It is also to think about the relationship between the social conditions of freedom and citizenship in a distinctively New Deal manner. The Court thus continued to mix notions of state non-interference with assertions of positive liberty and inquiry into the social conditions of freedom.

\section{The Path to Same-Sex Marriage}

The path to recognizing a right to same-sex marriage consolidated the connection between the New Deal legacy and the post-Griswold era, linking nearly a century of jurisprudence on freedom and association in spheres beyond the political. The Court announced "intimate association" as a right, just as it announced worker association as a right. Along the way, it developed its conception of positive liberty.

The path began in Lawrence, which demonstrated the mixed traditions of negative and positive liberty developing in the jurisprudence. Like Casey, the Court began with negative liberty but then transitioned to a more positive notion of liberty:

Liberty protects the person from unwarranted government intrusions into a dwelling or other private places. In our tradition the State is not omnipresent in the home. And there are other spheres of our lives and existence, outside the home, where the State should not be a dominant

\footnotetext{
221. Id. at 852 .

222. Id.

223. Id. at 853

224. Id. at 856

225. Schacter, supra note 23 , at 759 .
} 
presence. Freedom extends beyond spatial bounds. Liberty presumes an autonomy of self that includes freedom of thought, belief, expression, and certain intimate conduct. The instant case involves liberty of the person both in its spatial and more transcendent dimensions. ${ }^{226}$

The Court thus began with "private places" and government noninterference but then moved to "other spheres of our existence," noting freedom's extension "beyond spatial bounds."227 The very mention of multiple spheres anticipates that the path from Griswold onward might be more capacious than one would think otherwise. ${ }^{228}$ And the Court's reference to action and conduct began to bring in the concept of exercise.

The Court then pivoted towards a New Deal-like move of identifying the exercise of freedom with association. It stated that the statutes in question violated the Due Process Clause because they "seek to control a personal relationship that, whether or not entitled to formal recognition in the law, is within the liberty of persons to choose without being punished as criminals." 229 It was not for the State to "define the meaning of the relationship" and its connection to "their dignity as free persons." ${ }^{230}$ The Court continued that "liberty gives substantial protection to adult persons in deciding how to conduct their private lives in matters pertaining to sex." 231 Here the Court focused on the relationship and its meaning, which was to be decided by the people themselves. It was an account of liberty based on the "dynamics among citizens." 232 The Court thus looked at the intimate relations within the sphere and explored how they connect to and contribute to the self-definition that occurs when the couple defines the meaning of the relationship. In discussing the stigma that sodomy laws can bring, the Court found the stigma, as Schacter notes, "objectionable because it deprives gay people of the respect they are owed in pursuing their intimate life choices." ${ }^{233}$ Thus, it is the case that, in keeping with the New Deal tradition, "the version of liberty offered by [Justice] Kennedy seems to go beyond a purely 'negative' concept of freedom to one more 'positive,' in which people are entitled to more than a right to be left alone by government." 234

Windsor provided more mixed results. When the Supreme Court decided the constitutionality of Section 3 of the Defense of Marriage Act, ${ }^{235}$ which

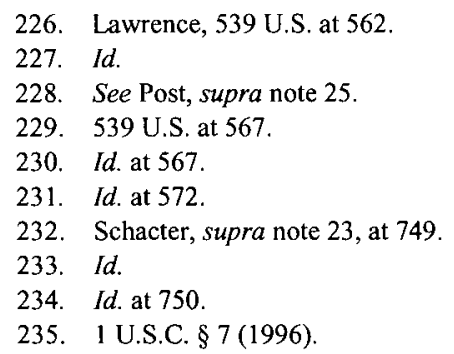


provided a federal definition of marriage denying federal recognition to same-sex couples who were married in the several states, the case was ripe for a consolidation of substantive due process doctrine around association. Yet, in striking down Section 3, the majority never used the words substantive due process. At the same time, the Court called the deprivation levied by Section 3 of DOMA one "of an essential part of the liberty protected by the Fifth Amendment." 236 The Court also explained that Section 3 "violates basic due process and equal protection principles." 237 Windsor therefore appeared to be a substantive due process case, although its focus on "equal liberty" suggests that it provided a modern variant of "hybrid" equal protection-substantive due process claims. ${ }^{238}$

At the same time, the Court avoided the pitfalls that have plagued the doctrine, framing marriage not around the architecture of privacy, as had Griswold, but as a "commitment to one another before [the couple's] children, their family, their friends, and their community."2399 It concluded that DOMA "undermines both the public and private significance of statesanctioned same-sex marriages," telling couples that their unions are "unworthy of federal recognition," and thereby "demeans the couple, whose moral and sexual choices the Constitution protects." ${ }^{240}$ This language therefore focused on the commitment that marriage reflects-not simply as an act of privacy - in the social world and community, and on the choices that the couple makes. It was both positive in its discussion of choicemaking and associational in its discussion of the union. It was also, with its turn towards dignity, responsive to the social conditions of freedom.

However promising these moves, the lack of clarity about the doctrinal position of the case is troubling. Justice Scalia, in his dissent, stated that the "majority never uttered the dread words 'substantive due process,' perhaps sensing the disrepute into which the doctrine has fallen, but that is what [its holding] mean[s].".241 Thus, just when the Supreme Court appeared to return to a capacious notion of substantive due process in Lawrence, it opened itself to the argument that it was turning away from a troubled doctrine in Windsor. The Court's understanding of the doctrine's complicated history, one could easily suspect, is somewhere in the mix.

Same-sex marriage offered the Court an opportunity to further clarify the meaning of freedom in the context of association, tying the knot between the New Deal repudiation of Lochnerism and the post-Griswold contribution to its identification of freedom in association.

236. United States v. Windsor, 570 U.S. _, slip. op. at 19 (2013).

237. Id.

238. See Tribe, supra note 21, at 1898; Yoshino, supra note 2, at 749-750.

239. Id at 20.

240. Id. at 22-23

241. Windsor, supra note 236 , at 17 (Scalia, J., dissenting). 
In reasoning about marriage in previous cases, the Court did not have much to say about the meaning of association. In Loving, the Court struck down a miscegenation law on both equal protection and substantive due process grounds. It did the latter, though, mostly in passing. The Court concluded that the laws preventing the Lovings from procuring an interracial marriage deprived them "of liberty without due process of law in violation of the Due Process Clause of the Fourteenth Amendment."242 It continued, "The freedom to marry has long been recognized as one of the vital personal rights essential to the orderly pursuit of happiness by free men." 243 The Court did not say much more, making any explication of liberty as it touches upon marriage an afterthought. Griswold, as I described above; did not consider the right of the Griswolds to marry, but did describe the marriage relationship as "a right of privacy older than the Bill of Rights." 244

In Obergefell v. Hodges, in which the Court found that the Due Process Clause granted same-sex couples the right to marry, the majority explicitly referenced association and developed a conception of it in greater detail than other precedents had. The Court both linked marriage to a "right to personal choice ... inherent in the concept of individual autonomy" and to intimate association, referring to marriage's importance in "support[ing] a twoperson union unlike any other in its importance to the committed individuals." 245 The Court also announced a "right... to intimate association," ${ }^{246}$ and did not tie this right to the right of privacy, as had Griswold. The Court's connection of individual autonomy with intimate association provides a stronger account of choice-making and bilateralism than the one developed in Griswold, an endeavor aided by the Court's continued reference to individual and relational choice-making in Lawrence and Windsor. By connecting individual autonomy and associational choicemaking the Court provides a stronger basis for protecting intimate association as an exercise of freedom.

In one sense, then, the Court consolidated the identification of "nonpolitical" association with freedom. It continued the turn that the New Deal began of opening up private spheres of life as sites of important decisionmaking and anchoring liberty in exercise and association. A purely negative conception of freedom based on limited government would not be useful for explaining why the government should protect the ability of same-sex couples to enter into civil marriage - that is, would not show the relationship between governmental recognition (rather than non-

242. Loving v. Virginia, 388 U.S. 112 (1967).

243. Id.

244. 381 U.S. at 486.

245. 576 U.S. _ (2015), slip. op. at 13.

246. Id. at 14 . 
interference) and liberty. It would also be poorly positioned for explaining why this liberty interest is fundamental to citizens, since that question focuses on the content of personal liberty and requires the sensitivity to the social dimensions of freedom that the Court demonstrates.

At the same time, the opinion's analytic force became somewhat weak as the Court turned to identifying why liberty resides in intimate association. First, the Court mixed focus on the romantic bond aspects of marriage with associational choice-making. The majority began with the notion that "[c]hoices about marriage shape an individual's destiny"247_gesturing towards a positive account of liberty-but then repeatedly referred to marriage as an "enduring" 248 or "intimate bond," 249 emphasizing its aspects of spirituality, ${ }^{250}$ companionship, ${ }^{251}$ and intimacy. ${ }^{252}$ Drawing on the New Deal conception, the Court could have emphasized more how marriages exemplify a form of association where persons agree to join together to make important decisions with mutual regard, making a commitment to govern important aspects of their lives together, and to make life plans with, or at least in consideration of, each other, from childbirth to childrearing, to where and how to live, to what plans to make about the future vis-à-vis careers, community, public life, and the like, as the Massachusetts Supreme Court did in its decision recognizing a state and federal right to same-sex marriage. ${ }^{253}$ The Court gives an account of marriage that is in some ways like the account in Griswold-mystic and spiritual-rather than one focused more on equal respect and choice-making.

Second, and relatedly, the Court conceived of marriage as the cornerstone of government. 254 This conception is linked to a notion of marriage providing societal stability and harkens to an era when private spheres were conceived of as ordering themselves - when personal life was thought to order naturally to achieve liberty - rather than speaking to how gender and societal relations had transformed in important ways, and therefore in a sphere-sensitive matter. Indeed, Griswold's most New Deal-like move, which Obergefell consolidates, is to reason from the premises of political association as an exercise of freedom towards an account of intimate

247. Id.

248. Id., slip. op. at 12 .

249. Id., slip op. at 13.

250. Id.

251. Id., slip op. at 14.

252. Id.

253. See, e.g., Goodridge v. Dep't of Public Health, 798 N.E.2d 941, 955 (Mass. 2003) (holding that same-sex couples had the right to civil marriage under the federal and Massachusetts constitutions and noting that the important decisions that married couples made together "touch[] nearly every aspect of life and death").

254. 576 U.S. _ (2015), slip op. at 16. 
association as one, and not vice versa. ${ }^{255}$ The intuition that self-consciously planning a future together and making critical choices together is an exercise of freedom extends from political liberty, to labor organization, and through marriage. It fits more neatly in modern American constitutional reasoning about freedom than does the intuition that "marriage is the image of order and peace."'256 And, finally, the Court's valorization of marriage, which is one institutional form of ordering, is inapt given its hook with the right of intimate association-a concept that does not specify the institutional form of the association and can endure beyond marriage ${ }^{257}$ (and indeed has particular resonance in a world where marriage as an institutional form is waning). 258

Still, the Court's affirmation of intimate association as an exercise of the liberty protected by the Constitution connects Obergefell to the fuller history of the repudiation of Lochnerism. It draws a century of constitutional argument, both in the Court and across the federal branches, into a line of reasoning about mutual association as an exercise of freedom. From the image of self-government, and its active notion of political liberty, New Dealers drew out an image of economic liberty in the labor union. The post-Griswold era would draw out the image at an even smaller unit, linking the intimate association of the married couple with liberty in fits and starts in Griswold, and more firmly in Obergefell. This is a history that, when fully understood, reveals something remarkable about the arc of American constitutional reasoning about freedom and association. It signals that freedom inheres in more than the right to be let alone and indeed in the important choices we make together in association in life's many domains.

\section{CONCLUSION}

Judges and scholars are haunted by the ghost of Lochnerism. That haunting speaks as much to remembering as it does to forgetting. Lawyers have forgotten the way that the architects of the New Deal era redefined economic liberty around worker association in a stunning affront to Lochnerism. Remembering the constitutional history that the architects offer, though, challenges the disjuncture posited between the "Lochner era" and the post-Griswold era. It offers, instead, a rich, if uneven narrative

255. For a critique of how this image of marriage as the foundation of societal order relies upon historical tropes associated with coverture, see Allison Anna Tait, The Return of Coverture, $114 \mathrm{MiCH}$. L. REV. FIRST IMPRESSIONS _ (2015).

256. Id. quoting DE TOCQUEVILLE, DEMOCRACY IN AMERICA, supra note 68, at 309.

257. See Serena Mayeri, Marriage (In)equality and the Historical Legacies of Feminism, 6CALIF L. REV. CIRCUIT 126, 134 (2015) ("Obergefell does not bear the marks of feminism's second legacythe campaigns against discrimination based on nonmarital status.")

258. See, e.g., Andrew L. Yarrow, Falling Marriage Rates Reveal Economic Fault Lines, N.Y. TIMES, Feb. 6, 2015. 
spanning over a century about freedom and association in spheres beyond politics - moving from the labor union to the marital union.

The arc of that story, narrowing from the broadly political to the intimately personal, suggests another historical shift, perhaps a greater one. To return to the martial union is to recall that political economy was once derived from household economy, ${ }^{259}$ and to see that the path of modern American constitutionalism has been to reason instead from the political towards the personal. Political association has become an image of the exercise of freedom with resonance beyond its own boundaries. (Andrew S. Skinner ed., 1966). 